\title{
Building Structure Mapping on Level Terrains and Sea Surfaces in Vietnam
}

\author{
Khanh D. Ngo ${ }^{1}$, Son V. Nghiem ${ }^{2, *(\mathbb{D})}$, Alex M. Lechner ${ }^{3} \mathbb{D}$ and Tuong T. Vu ${ }^{4} \mathbb{D}$ \\ 1 School of Environmental and Geographical Sciences, University of Nottingham Malaysia, Semenyih 43500, \\ Selangor, Malaysia; hgxdn1@nottingham.edu.my \\ 2 NASA Jet Propulsion Laboratory, California Institute of Technology, Pasadena, CA 91109, USA \\ 3 Lincoln Centre for Water and Planetary Health, University of Lincoln, Brayford Pool, Lincoln LN6 7TS, UK; \\ alechner@lincoln.ac.uk \\ 4 Faculty of Engineering and Science, Curtin University, Miri 98009, Sarawak, Malaysia; \\ tuongthuy.vu@curtin.edu.my \\ * Correspondence: son.v.nghiem@jpl.nasa.gov
}

Citation: Ngo, K.D.; Nghiem, S.V.; Lechner, A.M.; Vu, T.T. Building Structure Mapping on Level Terrains and Sea Surfaces in Vietnam. Remote Sens. 2021, 13, 2439. https://doi.org/ $10.3390 / \mathrm{rs} 13132439$

Academic Editor: Gilda Schirinzi

Received: 20 May 2021

Accepted: 19 June 2021

Published: 22 June 2021

Publisher's Note: MDPI stays neutral with regard to jurisdictional claims in published maps and institutional affiliations.

Copyright: (c) 2021 by the authors. Licensee MDPI, Basel, Switzerland. This article is an open access article distributed under the terms and conditions of the Creative Commons Attribution (CC BY) license (https:// creativecommons.org/licenses/by/ $4.0 /)$.

\begin{abstract}
Mapping building structures is crucial for environmental change and impact assessment, and is especially important to accurately estimate fossil fuel $\mathrm{CO}_{2}$ emissions from human settlements. In this regard, the objective of this study is to develop novel and robust methods using time-series data acquired from Sentinel-1 synthetic aperture radar (SAR) to identify and map persistent building structures from coastal plains to high plateaus, as well as on the sea surface. From annual composites of SAR data in the two-dimensional VV-VH polarization space, we determined the VV-VH domain for detecting building structures, whose persistence was defined based on the number of times that a pixel was identified as a building in time-series data. Moreover, the algorithm accounted for misclassified buildings due to water-tree interactions in radar signatures and due to topography effects in complex mountainous landforms. The methods were tested in five cities (Bạc Liêu, Cà Mau, Sóc Trăng, Tân An, and Phan Thiết) in Vietnam located in different socio-environmental regions with a range of urban configurations. Using in-situ data and field observations, we validated the methods and found that the results were accurate, with an average false negative rate of $10.9 \%$ and average false positive rate of $6.4 \%$ for building detection. The algorithm could also detect small houses in rural settlements and in small islands such as in Hòn Sơn and Hòn Tre. Over sea surfaces, the algorithm effectively identified lines of power poles connecting islands to the mainland, guard shacks in marine blood clam farms in Kiên Giang, individual wind towers in the off-shore wind farm in Bạc Liêu, and oilrigs in the Vũng Tàu oil fields. The new approach was developed to be robust against variations in SAR incidence and azimuth angles. The results demonstrated the potential use of satellite dual-polarization SAR to identify persistent building structures annually across rural-urban landscapes and on sea surfaces with different environmental conditions.
\end{abstract}

Keywords: building structure mapping; Sentinel-1 SAR time series; Sentinel-2 NDVI; geomorphon; Google Earth Engine

\section{Introduction}

Accurately mapping urban infrastructure is considered a high priority, not only for resource and service allocation and administration, but also for addressing environmental, socioeconomic, and geopolitical issues [1,2]. Extensive information on urban land use, including urban construction and green coverage, helps planners prepare and arrange the structure of the urban transportation, water and green system, and determine the scale and directions of future urban development in urban master planning processes [3]. Moreover, crucial to the successful implementation of the Paris Agreement within the United Nations Framework Convention on Climate Change (UNFCCC) are accurate mapping and monitoring of greenhouse gases such as $\mathrm{CO}_{2}$ [4]. Currently, fossil fuel $\mathrm{CO}_{2}$ (FFCO2) emission is 
estimated with nighttime light (NTL) data as a proxy for human settlements, which can be improved by maps of physically defined building structures [5].

SAR data have a high spatial resolution ranging from 10 to $100 \mathrm{~m}$, and are collected piecewise at different times over different areas of the world regardless of darkness and cloud cover conditions [6]. SAR data have been utilized to characterize urban and suburban extents with reliable results [7-9]. For example, geospatial datasets such as the Global Urban Footprint (GUF) and World Settlement Footprint (WSF) products $[10,11]$ have been successfully derived from TerraSAR-X and TanDEM-X SAR data. Ban et al. [7] investigated the use of multi-temporal Sentinel-1A SAR and Sentinel-2A Multispectral Instrument (MSI) data for developing pilot global urban services. They found that Sentinel-1A SAR data in association with historical SAR data produced good results for new built-up area characterization.

Here, the objective of our study is to develop novel and robust methods using Sentinel1 SAR to identify and map persistent building structures that represent sustained human settlement and circumvent the limitations of NTL to improve estimation of FFCO2 emission. Temporary buildings such as pavilions in festivals or exhibition events exist temporarily for a short time (days to weeks) and therefore do not persistently represent true human settlements. This particular objective requires the detection of structures that are persistently built rather than being temporarily constructed. Such an approach necessitates a new development of an innovative method utilizing time-series SAR data to determine the building persistency, rather than past methods using data at a given time or at various disparate points in time. The new method demands that each pixel in a study area is consistently treated with a persistent time-series data record over a time duration (e.g., semi-annual, annual, or interannual), instead of using usual change detection methods from multi-temporal images acquired on different days in different years [12-15].

The method developed in this study considers building structures on complex landscapes and sea surfaces. In both cases, SAR signatures of the background geophysical media on land and sea can widely vary as functions of incidence and azimuth angles [16-20], which need to be accounted for in the development of a robust algorithm. On land, complex topography can change the local incidence angle at different azimuth looks and cause polarization mixing of transverse electric and transverse magnetic fields at the medium interface [16], which alters backscatter signatures and leads to false building identification. Another complicated challenge is that strong reflections of radar signals from water surfaces of rivers, lakes, reservoirs, or wetlands cause intensive scattering from nearby trees that appear similar to building structures. Sea surfaces may have a wide range of radar return under different wind speeds and wind directions [18,19], introducing sea clutter and confounding the capacity of SAR to detect building structures in the marine environment.

In view of the above challenges and complexities, a new algorithm was developed to address the problem of detecting persistent building structures on land in different environmental and geophysical conditions and on sea surfaces under various wind speeds and directions beyond the capability of current methods. The algorithm was tested across urban, suburban, rural, and natural areas on land and over sea surfaces in Vietnam using Sentinel-1 SAR time series data. First, we introduce a novel method to identify building structures using the two-dimensional (2-D) space of VV-VH polarization of the SAR data. Next, we describe a method for accuracy assessment and present the case studies for five cities with different developmental and environmental conditions. Moreover, we show maps of man-made structures from small shacks to large oil rigs on sea surfaces.

Regarding the advances in the new method, we highlight (1) the advantage of utilizing the two-dimensional (2-D) space of VV-VH for building structure mapping to robustly resolve the issue of radar backscatter incidence and azimuth angle dependence; (2) the ability of consistent time-series Sentinel-1 SAR to identify persistent buildings in a multitude of environmental conditions across the rural-urban continuum; (3) the utilization of multiple SAR signature interactions between trees and water surface to correct for building misclassification; (4) the use of the geomorphon concept and its applications [21-24] to 
account for effects of complex topography; and (5) the SAR ability to detect stationary structures or installations that are maintained on sea surfaces. Finally, in the discussion and conclusion, we note future research extensions with multiple international SAR datasets to support the Paris Agreement on climate change, through the potential improvement in the estimation of FFCO2 emission using data products of persistent building structures to represent true settlements.

\section{Methods}

We present a new robust approach to identify persistent building structures, paying particular attention to the effects of the terrain and water-tree radar signal interactions. The analysis, including image processing, mapping, and accuracy assessment, was carried out using the Google Earth Engine (GEE) platform, Geographic Resources Analysis Support System (GRASS), and ArcGIS software. The flow chart in Figure 1 summarizes the overall methods in which each component is described in further detail below.

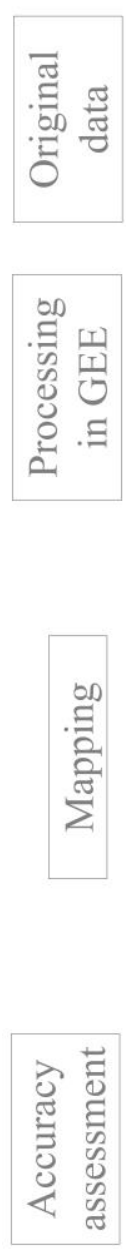

\section{REMOTE SENSING IMAGERY}

- Sentinel-1A SAR: 35 time series images, VV-VH polarization, $10 \mathrm{~m}$ resolution.

- Sentinel-2 MSI: 20-27 images (cloudiness $<20 \%$ ), $10 \mathrm{~m}$ resolution.

- Shuttle Radar Topography Mission (SRTM): 30 m resolution.

- Apply orbit file.

IMAGE CALIBRATION

- Radiometric calibration.

- Terrain correction.

- Speckle filtering (using a multi-temporal 3-point mean filter).

- Cloud masking (Sentinel-2 MSI).

\section{BUILDING DOMAIN CLASSIFICATION}

- Extract pixel values for all land cover types (both VV and VH polarization, all incidence angle bins and azimuth looks).

- Plot 2-D space of VV-VH.

- Determine threshold to classify building domain.

- Count the number of times that each pixel identified as building.

- Determine the optimal building count threshold.

- Calculate NDVI to account for effects of water-tree interactions.

- Calculate geomorphons to account for effects of topography.

\section{1}

\section{ACCURACY CALCULATION}

- Collect in-situ ground truth data.

- Calculate mapping accuracy based on ground truth data, Google Earth Image, ArcGIS base map.

Figure 1. Processing and mapping workflow.

\subsection{Image Processing}

All Sentinel-1 SAR images were pre-processed using the GEE platform to derive the backscatter coefficient in decibel $(\mathrm{dB})$ for each pixel through the following steps: applying orbit file, thermal noise removal, radiometric calibration and terrain correction using the Shuttle Radar Topography Mission (SRTM) 30-m topographic data, and then spatial coregistration of temporal data based on a referenced image so that the time series has the same coordinate system. 
To reduce speckle noise in SAR images, we used a multi-temporal 3-point mean filter (a moving average over a given time window) that would be computationally effective for noise reduction. The calculation was made as follows:

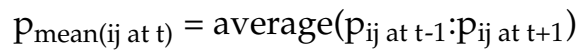

In (1), $p_{\text {mean(ij at } t)}$ is the output pixel value at location $i, j$ (i: numbers of image rows, $j$ : numbers of image columns) at time $t ; p_{i j}$ at $t-1$ is the input pixel value at location $i, j$ at time $t-1$; and $p_{i j}$ at $t+1$ is the input pixel value at location $i, j$ at time $t+1$.

In this study, the values of $t$ had a range of 1 to 35 (35 being the total number of SAR images in the time period under consideration). After the mean calculation, we then removed the first and last images in the time-series and only 33 images were used for further analysis. This time series spans approximately 1.3 years within which building structures need to persistently exist to be detected.

We applied the calculation to obtain the geometric mean in $\mathrm{dB}$ and the arithmetic mean in the linear unit (including conversion from $\mathrm{dB}$ to linear values). As an example, Figure 2 shows the raw backscatters, geometric mean, and arithmetic mean. The multi-temporal 3-point mean filter provided sufficient noise reduction and preserved temporal fidelity. We found that results from the geometric mean in $\mathrm{dB}$ and the arithmetic mean (converted back to $\mathrm{dB}$ ) were similar, so we used the geometric mean for effective computations without the conversions back and forth between $\mathrm{dB}$ and linear units.

(a)

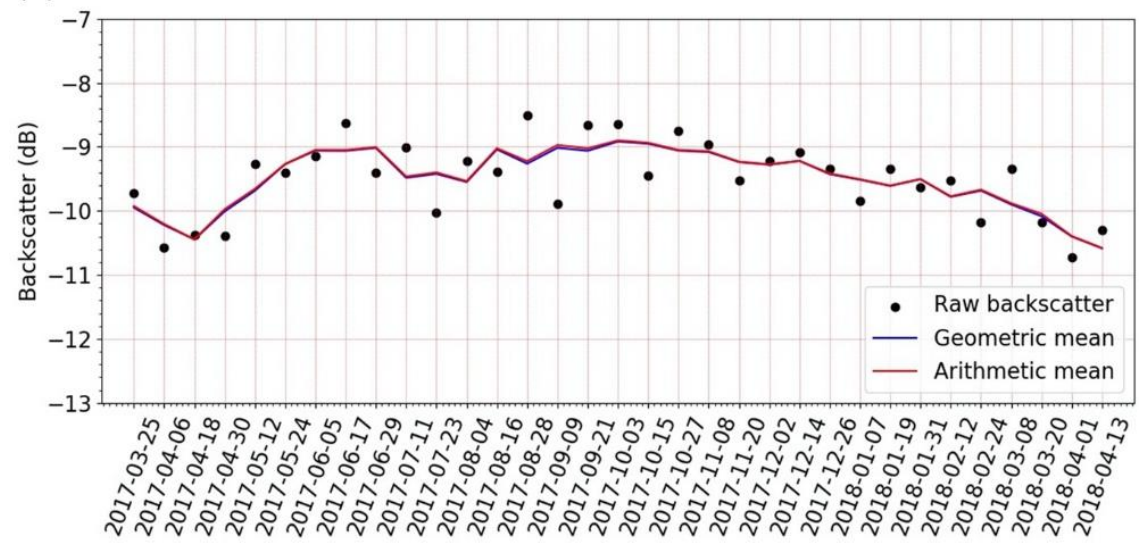

(b)

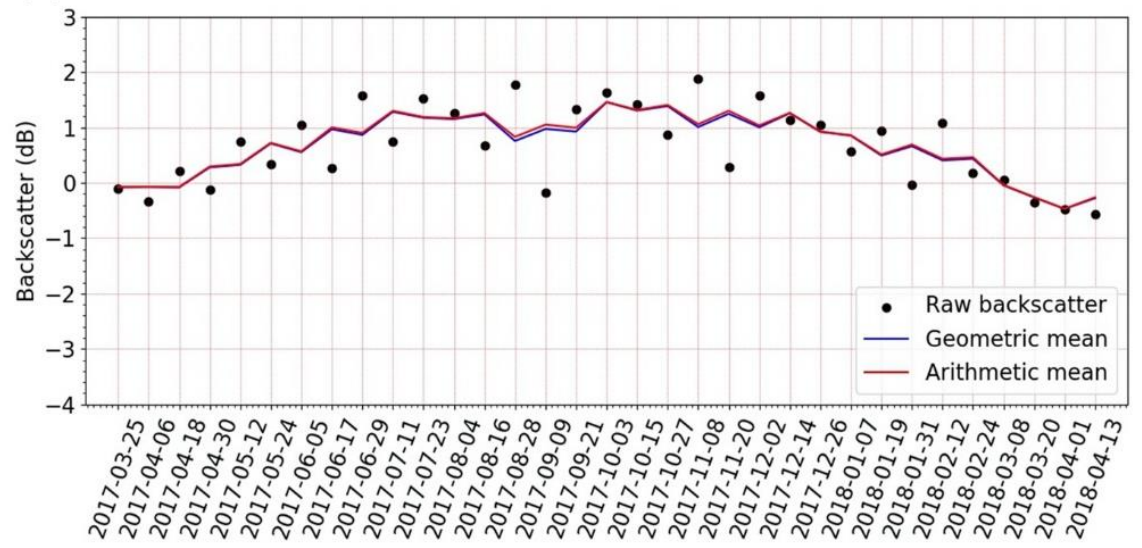

Figure 2. Example of filtering of raw Sentinel-1A SAR time series for (a) VH and (b) VV polarizations over Bạc Liêu city. 


\subsection{Mapping}

We used the 2-D space of VV-VH to characterize the building domain (Figure 3). The incidence angle in SAR images may have significant effects on backscatter values across the radar swath. To determine how backscatter changes as a function of incidence angle for various types of land cover, we separated VV and VH data for each incidence angle bin at 35,38 , and 42 degrees. Then, for each incidence angle bin and azimuth direction (ascending versus descending), we made a scatter plot with VV polarization for the $\mathrm{x}$ axis and $\mathrm{VH}$ polarization for the y-axis using the 3-point mean backscatter filter for all types of land cover including buildings, trees, paddy fields (such as rice paddies), and aquaculture areas (such as shrimp farms) as shown in Figure 3. From the scatter plot, we found that the VV-VH domain for the building type stands out clearly and distinctively, independent of the effects of incidence and azimuth angles. However, there is a minor overlap between the building and tree domains due to high backscatter from water-tree radar signal interactions (to be addressed later in this section). Next, we determined the thresholds in the 2-D VV-VH space to define the domain specifically pertaining to building structures on land and on the sea surface. A pixel was assigned to a building class on land if it satisfied the following conditions: VH backscatter greater than $-12 \mathrm{~dB}(\mathrm{VH}>-12 \mathrm{~dB})$ or VV backscatter greater than $-5 \mathrm{~dB}(\mathrm{VV}>-5 \mathrm{~dB})$. While on the sea, building pixels were assigned where $\mathrm{VH}$ backscatter greater than $-20 \mathrm{~dB}(\mathrm{VH}>-20 \mathrm{~dB})$ or VV backscatter greater than $-5 \mathrm{~dB}(\mathrm{VV}>-5 \mathrm{~dB})$. If a pixel did not satisfy that condition, it would be assigned to a non-building class.

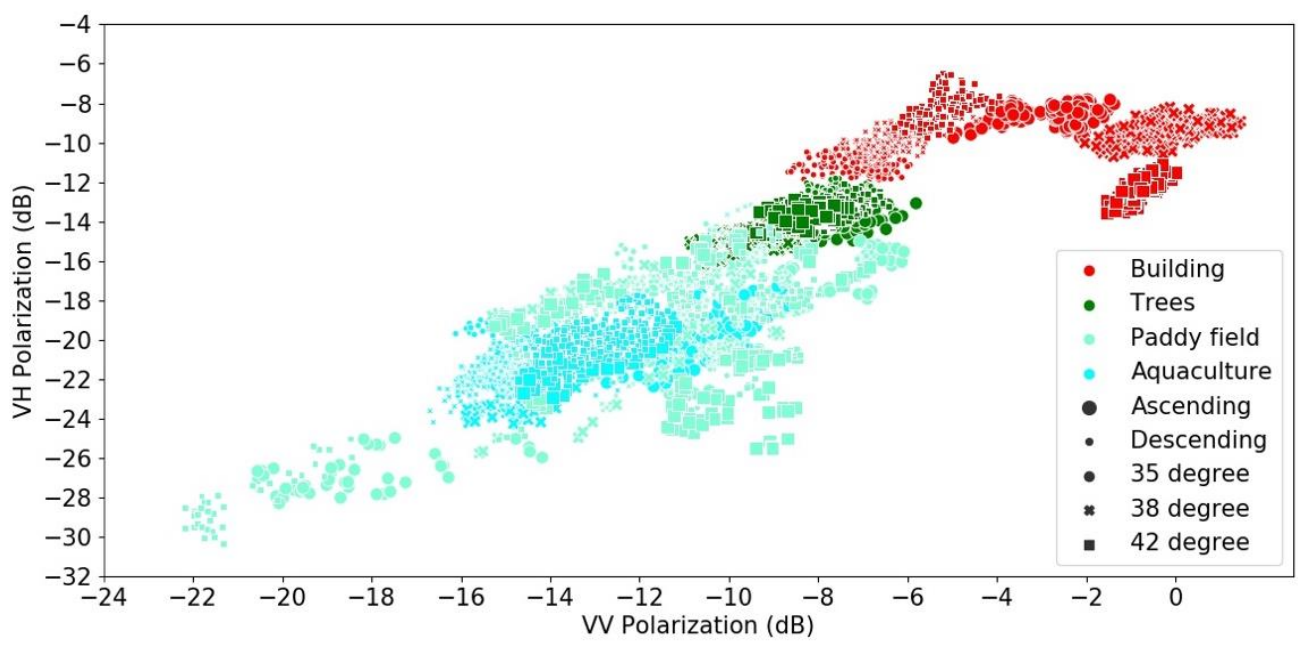

Figure 3. Multi-temporal backscatters of building structures and other land cover classes in the 2-D space for $\mathrm{VV}$ on the horizontal axis and $\mathrm{VH}$ on the vertical axis in $\mathrm{dB}$.

To account for missing building pixels, we applied the VV and VH thresholds to all Sentinel-1A images in the time series (33 images). We combined all output images (with value 1 for building pixels, and with value 0 for non-building pixels) to count the number of times that each pixel was identified as building. If pixel_ij was detected as a building T times out of the 33 images, then the count of pixel_ij was set to T. Each pixel in the combined output image could have a value of $\mathrm{T}$ from a minimum of 0 (for pixels in which buildings were never identified) to 33 (for pixels identified as buildings at all the times). To minimize misclassifying building pixels from real non-building pixels, we had to determine the optimal building count threshold (building_count_threshold) with the discrete derivative of building pixels $\left(\Delta_{\mathrm{m} \_n}\right)$ depending on where the $\Delta_{m_{-} n}$ curve became invariant or flattened. Pixel_ij was identified as a building if building_count_ij > building_count_threshold where the building_count_threshold could be from 1 to 33 . The discrete derivative of building pixels was calculated as follows:

$$
\Delta_{\mathrm{m} \_\mathrm{n}}=\mathrm{N}_{\text {threshold_m }}-\mathrm{N}_{\text {threshold_n }}
$$


where we have defined the terms: $\Delta_{\mathrm{m} \_n}$ for the derivative between thresholds $\mathrm{m}$ and $\mathrm{n}$, $\mathrm{N}_{\text {threshold_m }}$ for the number of building pixels at threshold $\mathrm{m}(1 \leq \mathrm{m} \leq 33)$, and $\mathrm{N}_{\text {threshold_n }}$ for number of building pixels at threshold $n(1 \leq n \leq 33)$. Based on the formulation given by Equation (2), discrete derivative curves were used to determine the optimal building count threshold applicable to all study cases. This method requires a building structure to exist persistently for a minimum period of about 4 months (see Appendix A).

Due to strong radar reflection, such as from water surface (e.g., rivers, lakes, reservoirs, or wetlands, etc.), nearby trees can have intense radar returns. Figure 4 illustrates watertree radar reflection interactions, where $\mathrm{T}$ represents the radar transmission direction and $\mathrm{R}$ represents the radar return direction. The terms $\mathrm{A}$ and $\mathrm{B}$ represent forward scattering mechanisms, and the terms $\mathrm{C}$ and $\mathrm{D}$ are backward scattering mechanisms. These account for multiple electromagnetic-wave interactions [17] involving scatterers (such as leaves, branches, and trunks of trees) and the interface between different media (such as the interface between water and air). The forward terms (A and B) give rise to strong scattering from water-tree interactions, causing backscatter enhancement [17] from trees to be similar to the backscatter from building structures. These effects result in a common range in the backscatter values of trees and building structures, contributing to the overlap of the building and tree backscatter signatures in the 2-D VV-VH space and thereby leading to some misclassification between these two land cover types.

To address the water-tree problem, we used the Normalized Different Vegetation Index (NDVI) [12] derived from the Multi-Spectral Instrument (MSI) aboard Sentinel-2 satellites. We used GEE to select Sentinel-2 MSI data on mostly-clear-sky days (cloudiness $<20 \%$ ) to compute NDVI in the same time period of the Sentinel-1 SAR data acquisition. We then calculated NDVI in each 10-m pixel and computed the average of $N$ largest values of NDVI (NDVI_avg_Nmax) in each pixel obtained over the time period under consideration. For each pixel that was classified as building, we reclassified the building pixels as non-building if NDVI_avg_Nmax > NDVI_threshold. We examined multiple cases for $\mathrm{N}=3,5,10$, and 15 and found NDVI_threshold to range from 0.25 to 0.5 in each case. Based on this assessment, we set the parameters to $\mathrm{N}=3$ and NDVI_threshold $=0.35$ as these values yielded optimal results in reducing most of the misclassified buildings, as seen in Figure $4 \mathrm{~b}$ before the correction and Figure $4 \mathrm{c}$ after the correction. This was necessary as many human settlements including small towns and big cities may have trees along rivers, lakes, and other water bodies.

On sloped surfaces in mountainous areas with a complex topography, the local incidence angle of radar transmission is not the nominal incidence angle with respect to a horizontal level surface. Moreover, a radar transmission signal at a given polarization (e.g., horizontal or vertical polarization) can excite both the transverse-electric (TE) and transverse-magnetic (TM) fields causing polarization mixing in the radar return signals [16]. These effects alter backscatter signatures and cause false building identifications.

To address the misclassification problem due to topography effects, we accounted for complex landforms in mountainous areas based on the geomorphon concept [21-24] to circumvent the ill-posed calculus of taking spatial derivatives from noisy topography data. We employed the SRTM digital elevation model (DEM) [25] derived from satellite SAR data to calculate geomorphons. A geomorphon represents one of the multiple possible landforms in terms of a three-dimensional morphological feature in ten different landform classes: flat, peak, ridge, shoulder, spur, slope, pit, valley, foot-slope, and hollow. The geomorphon approach uses three input parameters: inner search radius, outer search radius, and flatness threshold to calculate height differences [26]. The outer search radius was set to 10 pixels $(300 \mathrm{~m})$ and the inner search radius was set to 5 pixels $(150 \mathrm{~m})$, while the flatness threshold was set to 3 degrees. In our algorithm, a building pixel would be retained in the building type only when it was represented by a "flat" geomorphon. 

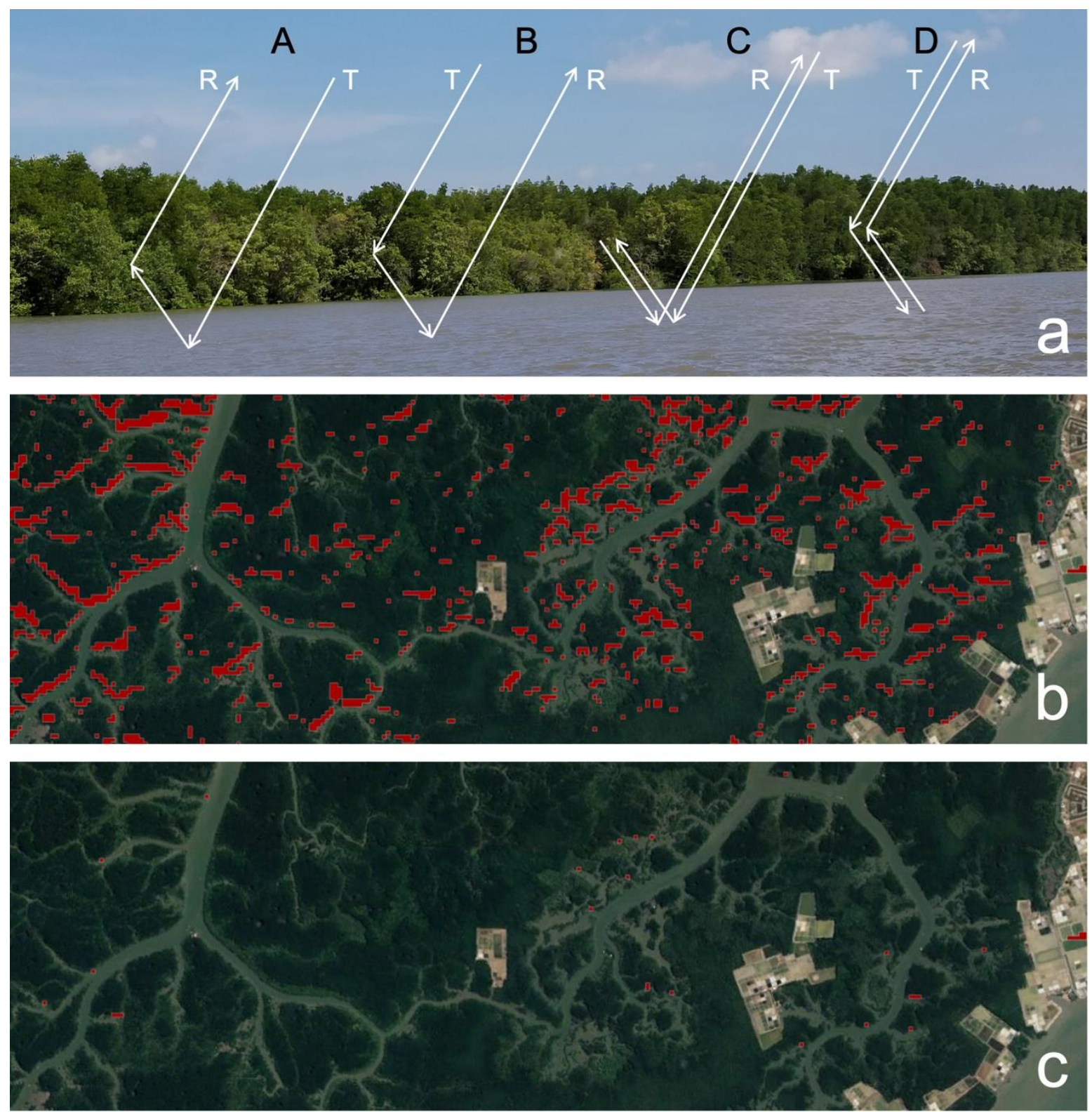

Figure 4. Effects of water-tree interactions on radar scattering mechanisms. Panel (a) illustrates water-tree radar interactions using a photograph taken on 20 May 2018 at $10^{\circ} 29^{\prime} 17.37^{\prime \prime} \mathrm{N}$ and $106^{\circ} 49^{\prime} 41.76^{\prime \prime} \mathrm{E}$ in the Cần Giờ Biosphere Reserve, a UNESCO wetland about 40 km southeast of Hồ Chí Minh City. Panel (b) shows misclassified buildings (red pixels) that were mostly removed as seen in Panel (c) after the corrections using Sentinel-2 MSI NDVI. Cần Giờ was the worst place for water-tree effects to test the efficacy of the correction method, where misclassification occurred all over the place as in Panel (b).

This approach using geomorphons means that structures built on mountain slopes may not be detected, while buildings can be identified on flat terrains in the lowlands in coastal plains or in valleys, or level plateaus at high altitudes where structures are usually built and persistently maintained. To illustrate the ability of the geomorphon method to account for topographic effects, Figure 5 shows that most of the misclassified buildings on the slopes of Hàm Cần Mountains ( 17 km northwest of Phan Thiết) were removed, while the true building area (a settlement in Lò To Village, Hàm Cần Commune, Hàm Thuận Nam District, Bình Thuận Province) was consistently detected on the relatively flat terrain near the foothill. 

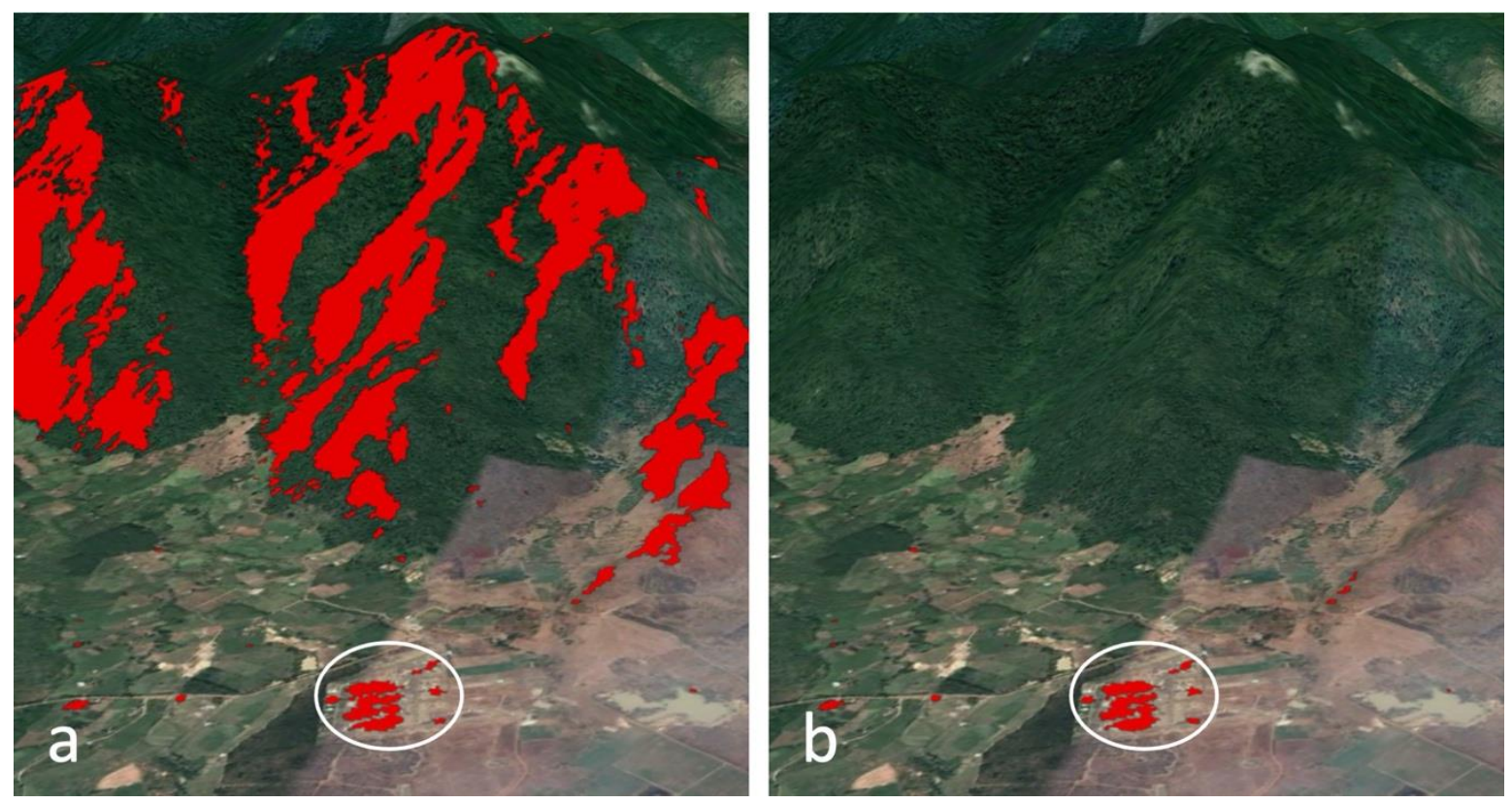

Figure 5. Detection of building structures (red areas) in an area around Hàm Cần Mountains without geomorphon correction (a), and with geomorphon correction (b). The ellipse marks a small settlement area (6.4 hectares) in Lò To Village where a built area was identified on the relatively flat terrain about $0.5 \mathrm{~km}$ from the foothill. The building structure map was overlayed on the topography using Google Earth Pro in a three-dimensional view.

\subsection{Ground Truth Data Collection and Accuracy Assessment}

In-situ ground truth data were collected in four cities (Bạc Liêu, Cà Mau, Sóc Trăng, and Tân An) in the Mekong Delta. Field work included traveling along main roads and waterways (e.g., rivers and canals) and taking field observations with geotagged photographs of different land cover types such as building structures (schools, hospitals, commercial centers, residential houses, etc.), trees (coastal forest, perennial trees, plantations), paddy fields (rice paddies), and aquaculture areas (shrimp farms). In addition, geotagged photographs were taken at different locations from rural to urban areas of Phan Thiết in the southern region of central Vietnam. The photographs were imported into ArcMap software and converted into points. These points were used as validation points in the accuracy assessment.

Based on in-situ ground truth data and field photographs together with high-resolution true color images in Google Earth ${ }^{\mathrm{TM}}$ and the ArcGIS base map, we assessed the quality of the mapping results. Since the algorithm identified a pixel as building or non-building rather than a range of fuzzy values, the accuracy assessment was carried out based on a set of four possible ensembles. Each ensemble population was represented by the number of counts of all pixel elements within each ensemble set. For these ensembles, the count parameters were assessed as: (1) the number of building pixels that were classified correctly as building (N_building), (2) the number of pixels that were misclassified as building while they were actually other land cover types (n_um), (3) the number of pixels that were misclassified as other land cover types while they were actually buildings (n_om), and (4) the number of other land cover types pixels that were classified correctly as other land cover types (N_others). Using the results of N_building, n_um, n_om, and N_others, the false negative rate and false positive rate were calculated in percentage as [27]:

$$
\begin{gathered}
\text { false negative rate }=\left[n \_o m /\left(n \_o m+N \_b u i l d i n g\right)\right] \times 100 \% \\
\text { false positive rate }=\left[n \_u m /\left(n \_u m+N \_o t h e r s\right)\right] \times 100 \%
\end{gathered}
$$




\subsection{Building Structures on Land}

We examined multiple cases in different environments on land. This study included four cities (Bạc Liêu, Cà Mau, Sóc Trăng, and Tân An) in the Mekong Delta on wet and level terrains with a tropical monsoon climate. In a stark contrast, we also studied one city (Phan Thiêt) in dry land extending from mountainous terrain in the west to the coast in the east in Bình Thuận, one of the most arid provinces in Vietnam at risk of desertification, making Phan Thiết vulnerable to moving sand dunes.

As in other cities in the Mekong Delta, due to socioeconomic developments, new settlements as well as other public infrastructures have been constructed in Bạc Liêu, Cà Mau, Sóc Trăng, and Tân An to meet housing and industrial demand. In recent years, these cities have suffered flooding from heavy rain, compounded by high tides in the rainy season. Bạc Liêu is a coastal city surrounded by rice farming and shrimp farming areas. This city is on a track to be a Class I urban (a regional central city) by 2025 and is likely to expand to 4950 ha by 2030 [28]. Being on a relatively flat terrain, in a landscape with a high density of rivers and canals, Cà Mau is planned to expand in all directions to adapt to climate change [29]. Sóc Trăng will be a Class II city (a provincial city) in 2025 and is expanding toward the east and west [30]. Located in Long An Province, Tân An is currently a central city and in Class II, and will be a Class I city by 2025 [31].

Famous as a coastal resort city in Bình Thuận Province in the south-central coast of Vietnam, Phan Thiết has received substantial investments in building large hotels and resorts. As mountains in the west of Phan Thiết can induce orographic effects resulting in intensive rains, this city suffers flash flooding compounded by the impacts of sea level rise on Cà Ty river, and beach erosion has also become a major issue. Despite transient intense rains in the mountains, Phan Thiêt is actually located in an arid land region of Bình Thuận in a magnificent coastal setting. Surrounded by extensive plantations of dragon fruit (Hylocereus undatus in the cactus family Cactaceae) and a beautiful shoreline, authorities have attempted to develop Phan Thiết into an environmentally sustainable and friendly city [32]. This region has been undergoing an intensive agriculture transformation by the development of extensive dragon fruit plantations, considered the "Dragon Fruit Kingdom" (or the "Dragon Kingdom" in short). The rural areas together with rapid urbanization due to the tourism boom in the city are creating the conditions for a dual rural-urban hotspot where both city areas and farmlands have been intensively and contemporaneously developed.

Generally, in Vietnam, each province has its own urban development strategies, depending on its geographical location and certain socioeconomic conditions pertaining to different urban classes. Tables 1 and 2 below summarize the population and infrastructure development standards for each urban class in Vietnam, which are applicable to the different cities in different provinces noted above. Our study sites were chosen to represent a range of urban patterns along the rural-urban continuum, consisting of different urban classes listed in Tables 1 and 2.

Table 1. Population scale standard [33].

\begin{tabular}{|c|c|c|c|c|c|c|c|c|c|}
\hline \multirow{3}{*}{ No. } & \multirow{3}{*}{ Standard } & \multirow{3}{*}{ Unit } & \multicolumn{7}{|c|}{ Urban Class } \\
\hline & & & \multirow{2}{*}{ Special } & \multicolumn{2}{|c|}{ I } & \multirow{2}{*}{ II } & \multirow{2}{*}{ III } & \multirow{2}{*}{ IV } & \multirow{2}{*}{$\mathbf{V}$} \\
\hline & & & & State & Province & & & & \\
\hline \multirow{2}{*}{1} & \multirow{2}{*}{$\begin{array}{l}\text { Population in urban and } \\
\text { suburban }\end{array}$} & \multirow{2}{*}{1000 people } & $\geq 6000$ & $\geq 5000$ & $\geq 1000$ & $\geq 500$ & $\geq 200$ & $\geq 100$ & \multirow{4}{*}{$4-50$} \\
\hline & & & 5000 & 1000 & 500 & 200 & 100 & 50 & \\
\hline \multirow{2}{*}{2} & \multirow[t]{2}{*}{ Population in urban } & \multirow{2}{*}{1000 people } & $\geq 4000$ & $\geq 3000$ & $\geq 500$ & $\geq 200$ & $\geq 100$ & $\geq 50$ & \\
\hline & & & 3000 & 500 & 200 & 100 & 50 & 20 & \\
\hline
\end{tabular}


Table 2. Infrastructure development standard [33].

\begin{tabular}{|c|c|c|c|c|c|c|c|c|}
\hline \multirow{2}{*}{ No. } & \multirow{2}{*}{ Standard } & \multirow{2}{*}{ Unit } & \multicolumn{6}{|c|}{ Urban Class } \\
\hline & & & Special & $\mathbf{I}$ & II & III & IV & V \\
\hline I & \multicolumn{8}{|c|}{ Infrastructure standard } \\
\hline I.1 & \multicolumn{8}{|c|}{ Housing } \\
\hline \multirow{2}{*}{1} & \multirow{2}{*}{ Average floor area } & $\mathrm{m}^{2}$ & $\geq 29$ & $\geq 29$ & $\geq 29$ & $\geq 29$ & $\geq 29$ & $\geq 29$ \\
\hline & & floor/person & $\overline{26.5}$ & 26.5 & $\overline{26.5}$ & $\overline{2} 6.5$ & $\overline{26.5}$ & $\overline{26.5}$ \\
\hline \multirow{2}{*}{2} & \multirow{2}{*}{ House rate } & \multirow{2}{*}{$\%$} & 100 & $\geq 95$ & $\geq 95$ & $\geq 95$ & $\geq 90$ & $\geq 90$ \\
\hline & & & 90 & 90 & 90 & 90 & 85 & 85 \\
\hline I. 2 & \multicolumn{8}{|c|}{ Public infrastructure } \\
\hline \multirow{2}{*}{1} & \multirow{2}{*}{$\begin{array}{l}\text { Settlement land, open-green land, parks, } \\
\text { traffic land }\end{array}$} & \multirow{2}{*}{$\mathrm{m}^{2} /$ person } & 61 & 61 & 61 & 78 & 78 & 78 \\
\hline & & & 54 & 54 & 54 & 61 & 61 & 61 \\
\hline \multirow{2}{*}{2} & \multirow{2}{*}{ Education } & \multirow{2}{*}{ buildings } & $\geq 40$ & $\geq 30$ & $\geq 20$ & $\geq 10$ & $\geq 4$ & $\geq 2$ \\
\hline & & & 30 & 20 & 10 & 4 & 2 & 1 \\
\hline \multirow{2}{*}{3} & \multirow{2}{*}{ Culture } & \multirow{2}{*}{ buildings } & $\geq 20$ & $\geq 14$ & $\geq 10$ & $\geq 6$ & $\geq 4$ & $\geq 2$ \\
\hline & & & 14 & 10 & 6 & 4 & 2 & 1 \\
\hline \multirow{2}{*}{4} & \multirow[t]{2}{*}{ Sports } & \multirow{2}{*}{ buildings } & $\geq 15$ & $\geq 10$ & $\geq 7$ & $\geq 5$ & $\geq 3$ & $\geq 2$ \\
\hline & & & 10 & 7 & 5 & 3 & 2 & 1 \\
\hline
\end{tabular}

\subsection{Building Structures on Sea Surface}

Vietnam has an extensive coastline $\left(>3400 \mathrm{~km}^{2}\right)$ with rich natural resources for aquaculture, fisheries, and offshore fossil and renewable energy. In the marine environment, this study included two offshore fossil oil fields (Bạch Hổ oil field and Sư Tử Đen oil field), a renewable wind power farm off the shore of Bạc Liêu, two islands (Hòn Tre and Hòn Sơn in Kiên Giang Province), and a marine aquaculture area for blood clam (Tegillarca granosa) farming also in Kiên Giang Province. These cases encompassed various types of stationary and persistent building structures on the sea surfaces including very large oil platforms, tall wind power towers, smaller power poles, and even very small individual guard shacks in the marine farm. On the sea surface, winds and waves can generate a large range of radar backscatter signatures that confound the detection of marine structures. The algorithm developed in this paper accounts for the problem of sea surface radar clutter to achieve a robust method for accurately identifying persistent marine structures using time-series Sentinel-1 SAR data.

\section{Results}

\subsection{Results for Building Structures on Land}

Figure 6 shows the results of the building classification and Figure 7 presents the building classification maps at a posting grid size of $10 \mathrm{~m}$ for the five cities (Bạc Liêu, Cà Mau, Sóc Trăng, Tân An, and Phan Thiêt) overlayed on the true-color ArcGIS base map. These maps show that most building pixels cluster around cities and disperse along roads and waterways emanating outward from urban to rural areas. The results from the building classification for each city reveal distinctive spatial patterns associated with their unique development history, socio-environmental constraints, population distribution drivers (Table 1) and infrastructure development standards (Table 2). The maps also highlight that these spatial patterns were captured by the classification method at a high spatial resolution, even identifying the footprint of individual buildings. 


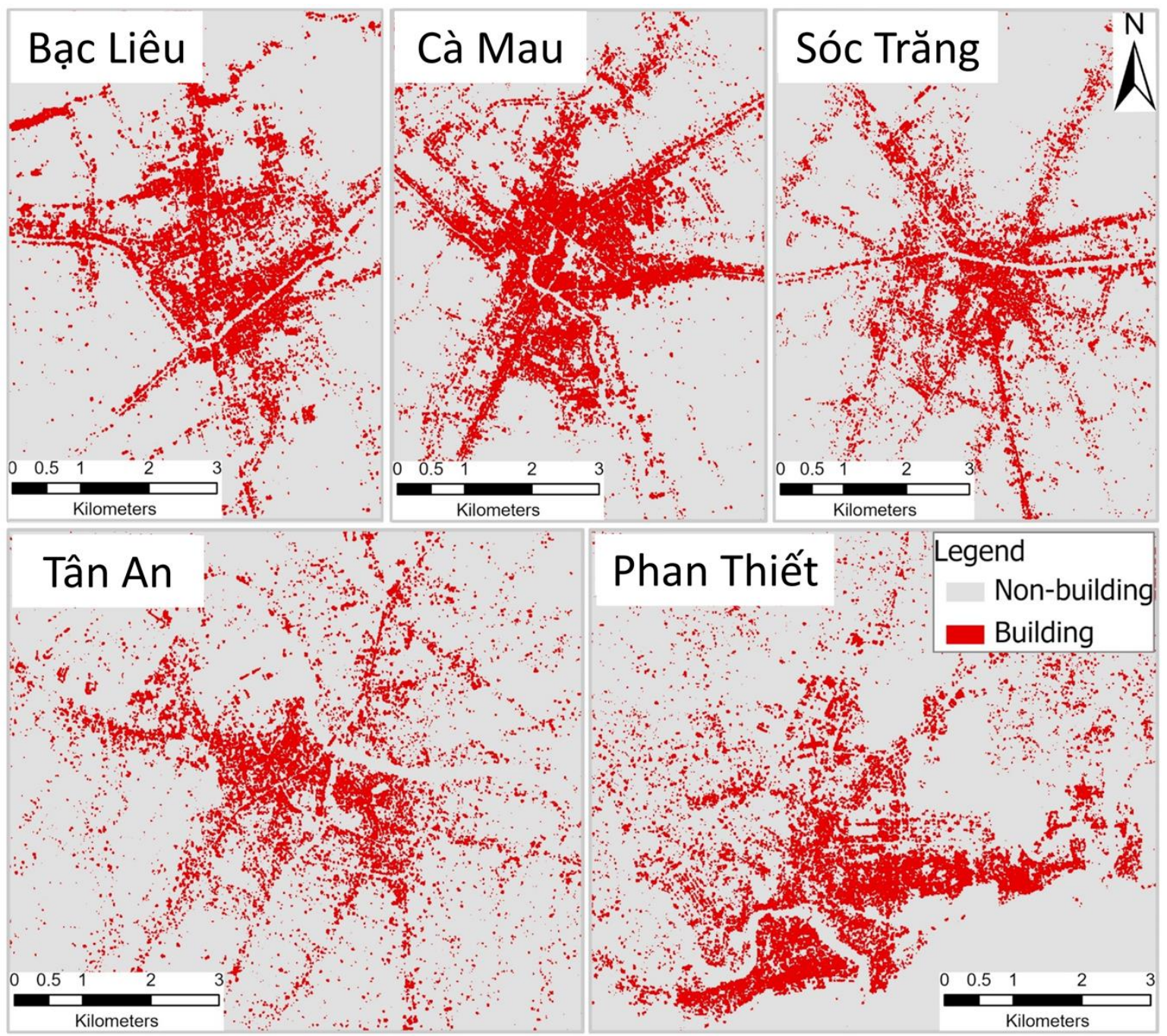

Figure 6. Classification map of five cities: Bạc Liêu, Cà Mau, Sóc Trăng, Tân An, and Phan Thiêt.

The Bac Liêu Province Public Administration Center and Bac Liêu Market in Ward 3 are found at the center. Built in the 1920s, Bạc Liêu Market was initially a busy trading place among Chinese and Vietnamese. Many old houses and shopping stores are present. In the 2010s, a wide range of public and private infrastructures such as Bạc Liêu university, Coopmart supermarket, Vincom shopping center, and Thanh Vũ hospital were newly built and expanded to meet population growth, labor demands, and economic development in Bạc Liêu. To comply with the Nation Urban Development Programme 2012-2020 and to meet housing demands, four new residential areas (Phường 2, Phường 5, Hoàng Phát, Tràng An) have been constructed. Along Trần Phú street and Quốc Lộ 1A streettwo main roads to city center-more houses, shopping stores, banks, and restaurants have also been constructed and are visible in the classified map. High building densities can also be seen at tourist places like Khu du lịch Nhà Mát on Hoàng Sa street by the seashore and at religious places like Quán Âm Phật Đài pagodas. North of Bạc Liêu city are agricultural rice paddy fields while south of the city has aquacultural shrimp farms. In these rural areas, fewer buildings were found on the rice paddies while more guard shacks were detected in shrimp farms. 


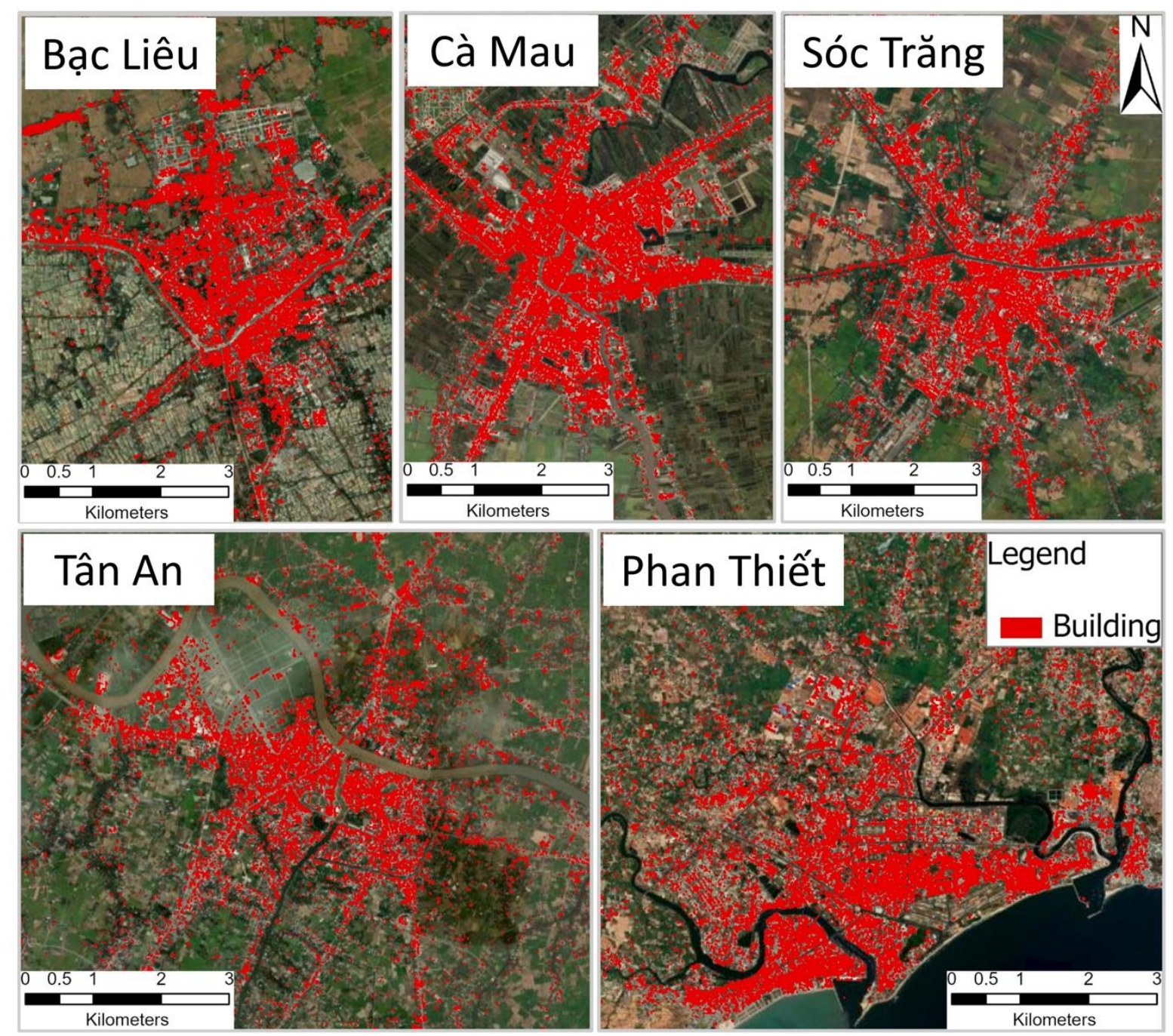

Figure 7. Classification map of five cities overlaid on ArcGIS base map: Bạc Liêu, Cà Mau, Sóc Trăng, Tân An, and Phan Thiết.

For Cà Mau, Tỉnh Ủy Cà Mau (Cà Mau Party Committee) and Ủy ban nhân dân tỉnh Cà Mau (Cà Mau Province's People Committee) in Ward 2 are at the center of Cà Mau. Cà Mau is expected to be Class I city in 2025 (see Table 1 for Class I population and Table 2 for Class I infrastructure), so many streets have been built and upgraded. The city has expanded in all directions with many houses along main roads and rivers in the directions of Bạc Liêu (the east of Cà Mau), Thới Bình District (the north and north-east of Cà Mau), U Minh District (the west of Cà Mau), and Đầm Dơi and Cái Nước District (the south of Cà Mau). One of the well-known residential areas in Cà Mau is the Gas-PowerFertilizer Complex housing area near the Cà Mau river. West, north, and east of Cà Mau are surrounded by extensive shrimp aquaculture where guard shacks can also be identified.

For Sóc Trăng, Tỉnh Ủy Sóc Trăng (Sóc Trăng Party Committee) and Ủy ban nhân dân tỉnh Sóc Trăng (Sóc Trăng Province's People Committee) in Ward 1 are located at the center of the city. Urban development in Sóc Trăng is primarily along main roads to the city and along the Maspero river. New residential and commercial areas (Trần Quang Diệu, Hạnh Phúc, Lê Duẩn) have been built in Ward 2, Ward 3, and Ward 4 to meet the city's population growth. The city has also expanded toward the south of the Maspero river along Trần Hưng Đạo and Lê Hồng Phong street and toward the north of Maspero river along Hùng Vương and Tôn Đức Thắng street. Sóc Trăng city is surrounded by paddy fields, so there are houses in small villages along irrigation canals. 
Tân An, Ward 1, is at the center, where Tỉnh Ủy Long An (Long An Party Committee) and Ủy ban nhân dân tỉnh Long An (Long An Province's People Committee) were built. From the center, the city has sprawled toward the south of the Vàm Cỏ Tây river. Many buildings and houses have been constructed in Ward 1 and Ward 2 along Bảo Định canal. As part of its progress toward a Class I city in 2025, the authorities of Tân An are constructing a wide range of residential areas (Vàm Cỏ riverside urban area; Tân An, Đồng Tâm residential area) along the Vàm Cỏ Tây river in Ward 6. The mapping also shows houses along Quốc Lộ $1 \mathrm{~A}$ street and Đường tỉnh 827 and 828 roads (connecting Tân An with other districts in the region). Tân An is surrounded by paddy fields and dragon fruit plantations. Unlike Bạc Liêu city, Tân An has more houses in rural areas, but these houses are scattered across the landscape and not found in parallel along main roads or rivers.

For Phan Thiết, Bình Thuận Province Public Administration Centre is at the center of the city. From the center, the residential areas have expanded to the north and north-east of the city center, such as the An Phú and Phú Tài-Phú Trinh residential areas. Commercial and medical service buildings (Coopmart supermarket, An Phước General Hospital) built to meet the social and health care demands are also visible in the map of building structures. Toward the south of the city center, more houses have been constructed along the Cà Ty river since this river is the main waterway connecting the sea and the fishing port at the Cà Ty river mouth. In response to the tourism boom in the city, a variety of policies for tourism development have been issued. Moreover, many large hotels and resorts have been built along the shore toward Mũi Né tourist site. Due to hilly terrain in the rural areas, houses are found scattered across the landscape and not along main roads like in Bạc Liêu, Cà Mau, and Sóc Trăng.

Evaluated with in-situ data and field observations, Table 3 shows the accuracy of building mapping in Bạc Liêu, Cà Mau, Sóc Trăng, Tân An, and Phan Thiết. Within these five cities, Bạc Liêu had the highest accuracy with false negative rate $=8.6 \%$ and false positive rate $=5.2 \%$. Phan Thiết had the lowest mapping accuracy with false negative rate $=13.3 \%$ and false positive rate $=8.2 \%$. Cà Mau, Sóc Trăng, and Tân An had similar mapping accuracies, with the false negative rate ranging from $9.5 \%$ to $11.9 \%$ and the false positive rate from $5.5 \%$ to $7.0 \%$. For all cities, the average false negative rate was $10.9 \%$, and the average false positive rate was $6.4 \%$ after the corrections for water-tree interactions and mountain topography effects.

Table 3. Accuracy assessment.

\begin{tabular}{ccccc}
\hline Cities & $\begin{array}{c}\text { N_Building } \\
\text { (pixels) }\end{array}$ & $\begin{array}{c}\text { N_Others } \\
\text { (pixels) }\end{array}$ & $\begin{array}{c}\text { False Negative Rate } \\
\text { (FNR) (\%) }\end{array}$ & $\begin{array}{c}\text { False Positive Rate } \\
\text { (FPR) (\%) }\end{array}$ \\
\hline Bạc Liêu & 320 & 330 & 8.6 & 5.2 \\
Cà Mau & 306 & 344 & 9.5 & 5.5 \\
Sóc Trăng & 310 & 340 & 11.4 & 6.1 \\
Tân An & 318 & 332 & 11.9 & 7.0 \\
Phan Thiết & 338 & 312 & 13.3 & 8.2 \\
\hline All cities & 1592 & 1658 & Average FNR $=10.9 \%$ & Average FPR $=6.4 \%$ \\
\hline
\end{tabular}

To illustrate the major difference in the ability of the SAR data product of persistent building structures to represent true settlements versus the excessive appearance of NTL extent, we examined the case of Phan Thiết city (capital of Bình Thuận Province), surrounded by vast dragon fruit plantations in the "Dragon Kingdom" of Vietnam. For NTL, we used the satellite Visible Infrared Imaging Radiometer Suite (VIIRS) Day and Night Band (DNB) data product (in units of $\mathrm{nW} / \mathrm{cm}^{2} / \mathrm{sr}$ ) with stray light correction [34] for February 2018 when the cloud cover was minimal to allow a good unobstructed observation of NTL. Figure 8 presents a map of persistent building structures detected by Sentinel-1 SAR around the area of Phan Thiết together with VIIRS NTL in Bình Thuận Province. 


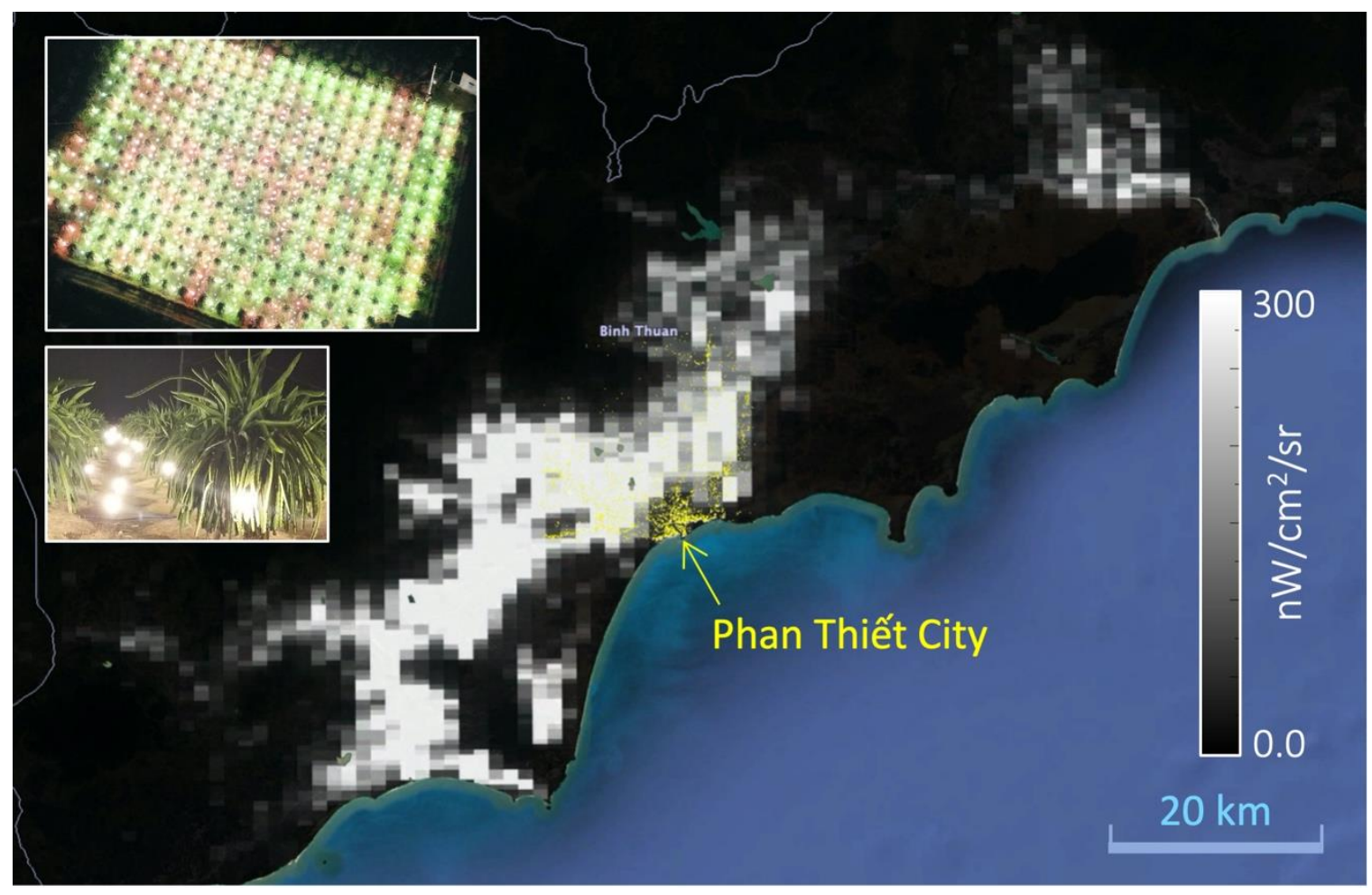

Figure 8. VIIRS NTL observations for Bình Thuận Province together with building structures detected by Sentinel-1 SAR represented by the yellow color in the area of Phan Thiết City. The insets are aerial (upper inset) and surface (lower inset) photographs of the dragon fruit lighting at night. The land-water mask used in this figure was obtained from the SRTM Water Body Data [25].

As shown in Figure 8, the extent of building structures around Phan Thiêt is only a small fraction of what is shown with the NTL over the dragon fruit plantations surrounding Phan Thiêt. Moreover, the NTL in the city was distinctively dimmer than the NTL from the dragon fruit plantation regions. This is because farmers use high-intensity artificial lights shining up toward the cactus canopy at night (Figure 8) to drive the photoconversion process of phytochromes [35] and increase the yield of dragon fruit production to multiple times per year [36]. The innovative use of night lighting has transformed the agriculture in this arid rural region of Bình Thuận Province, from rags to riches, with a dramatic expansion of dragon fruit plantations where earnings from this high-value cash crop approach a billion USD [37]. This example demonstrates that the vast extent of NTL over the rural regions of Bình Thuận exceeds by far the true urban areas, and will thereby lead to an excessive overestimation of FFCO2 emission using NTL as a proxy indicator of human settlements.

\subsection{Results for Building Structures on the Sea Surface}

This section presents the results of building structure mapping on the sea surface from huge oil platforms in major oil fields to tiny guard shacks in marine clam farms. The Bạch Hổ (White Tiger) oil field and Sư Tử Đen (Black Lion) oil field are two major offshore oil production areas in the Cửu Long basin due east of the Mekong Delta of Vietnam. The joint Vietnamese-Russian Vietsopetro operates at Bạch Hổ, while PetroVietnam with partners from ConocoPhillips, Korean National Oil, and others operates at Sư Tử Đen. Figure 9 reveals multiple persistent structures including oil platforms or oil rigs detected by our method in the period of March 2017 to May 2018 in the areas around Bạch Hổ (7 structures, within the frame in Figure 9a) and Sư Tư Đen (5 structures, within the frame in Figure 9b). A very rare image from Maxar acquired in 2006 captured an oil rig right at the location of Structure 710 in Sư Tư Đen and independently confirmed the SAR detection 
of this oil rig. In the Bạch Hổ and Sư Tử Đen areas, the centroid for each oil field structure is listed in Table 4.
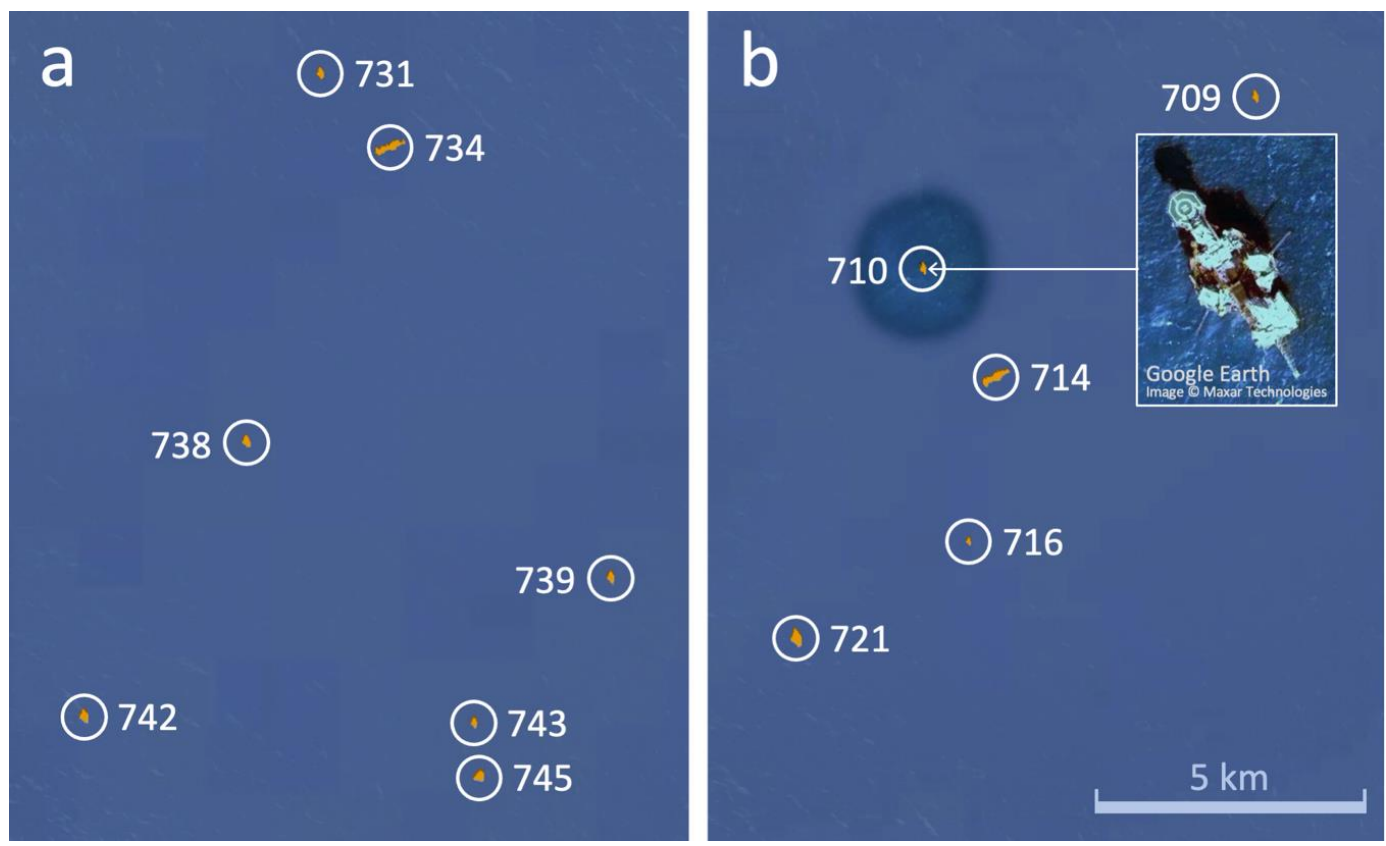

Figure 9. Detection of offshore structures (orange pixels inside circles) on the sea surface around (a) Bạch Hổ and (b) Sư Tử Đen oil fields. Each structure is assigned a unique identification (ID) number.

Table 4. Centroid locations of structures including oil platforms or oil rigs around Bạch Hổ and Sư Tử Đen oil fields. The ID of the structures detected in the oil fields correspond to those in Figure 9.

\begin{tabular}{cccc}
\hline Oil Field & Structure ID & Longitude $\left.\mathbf{(}^{\mathbf{0}}\right)$ & Latitude $\mathbf{(}^{\mathbf{}} \mathbf{)}$ \\
\hline \multirow{3}{*}{ Sư Tử Đen } & 709 & 108.4377899 & 10.46973133 \\
& 710 & 108.3818665 & 10.44124126 \\
& 714 & 108.3938675 & 10.42325497 \\
& 716 & 108.3894806 & 10.39616489 \\
Bạch Hổ & 721 & 108.3605118 & 10.38012123 \\
& 731 & 107.9596634 & 9.984884262 \\
& 734 & 107.9711685 & 9.972677231 \\
& 738 & 107.947319 & 9.923978806 \\
& 739 & 108.0084839 & 9.901568413 \\
& 742 & 107.9201202 & 9.878500938 \\
& 743 & 107.9855728 & 9.877530098 \\
\hline
\end{tabular}

In the littoral zone off the shore of Bạc Liêu, the first wind energy farm in southeast Asia was developed in an area of 540 ha producing 99.2 MW of electricity. Figure 10 shows each individual wind tower detected on the sea surface. The towers are aligned in parallel rows with a spacing of approximately $800 \mathrm{~m}$ as found in the building detection map. Each row has a maximum of eight towers with equal spacing between these towers $(\sim 250 \mathrm{~m})$. The wind tower closest to the sea dike on the shoreline was detected about $600 \mathrm{~m}$ away. 

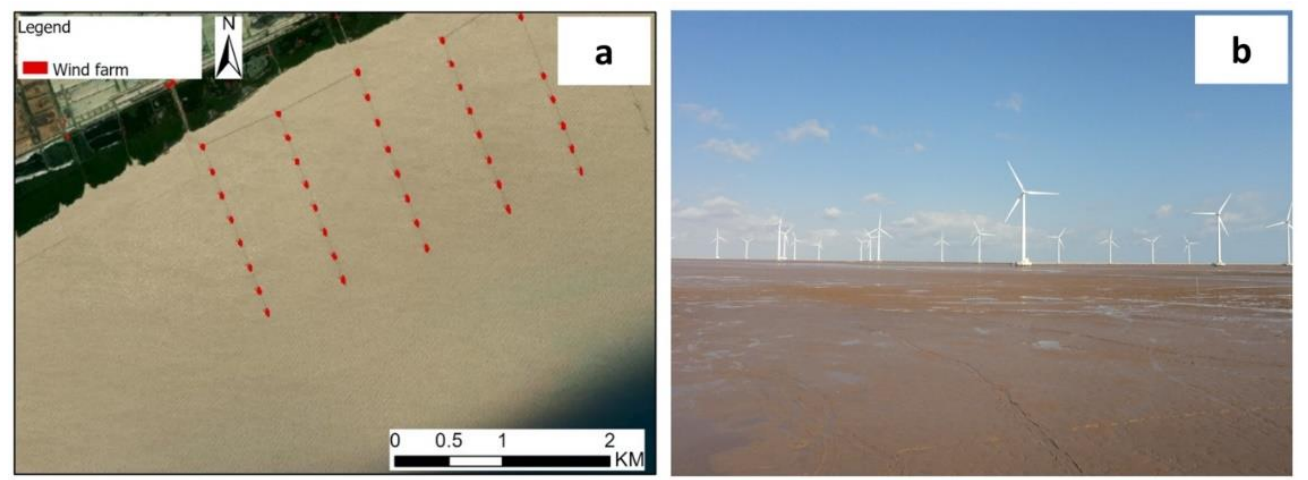

Figure 10. Wind energy farm off the shore of Bạc Liêu (a) wind-energy tower map detected from Sentinel-1 SAR and (b) ground-truth field photograph on 26 February 2019 at $9^{\circ} 13^{\prime} 49.76^{\prime \prime} \mathrm{N}$ and $105^{\circ} 48^{\prime} 12.12^{\prime \prime} \mathrm{E}$.

For the case of the Hòn Tre and Hòn Sơn islands, interestingly, not only houses in a small village could be captured on the shore land, but also the lines of power poles on the sea surface connecting the two islands to the mainland can be detected, as illustrated in Figure 11. The entire length of power lines connecting Hòn Tre to the mainland is $13 \mathrm{~km}$ including 27 poles, while the entire length for Hòn Sơn is $24.5 \mathrm{~km}$ with 49 poles. Since the two islands are close to the mainland, Southern Power Corporation (Tổng Công ty Điện lực miền Nam) built the electric power lines above sea surface rather than running power cables underwater, which is costly and commonly performed for islands far away from the mainland such as Phú Quốc island. The first power cables underwater in Vietnam connecting Phú Quốc to the mainland in Hà Tiên is $56 \mathrm{~km}$ long and cost approximately USD 100 million.
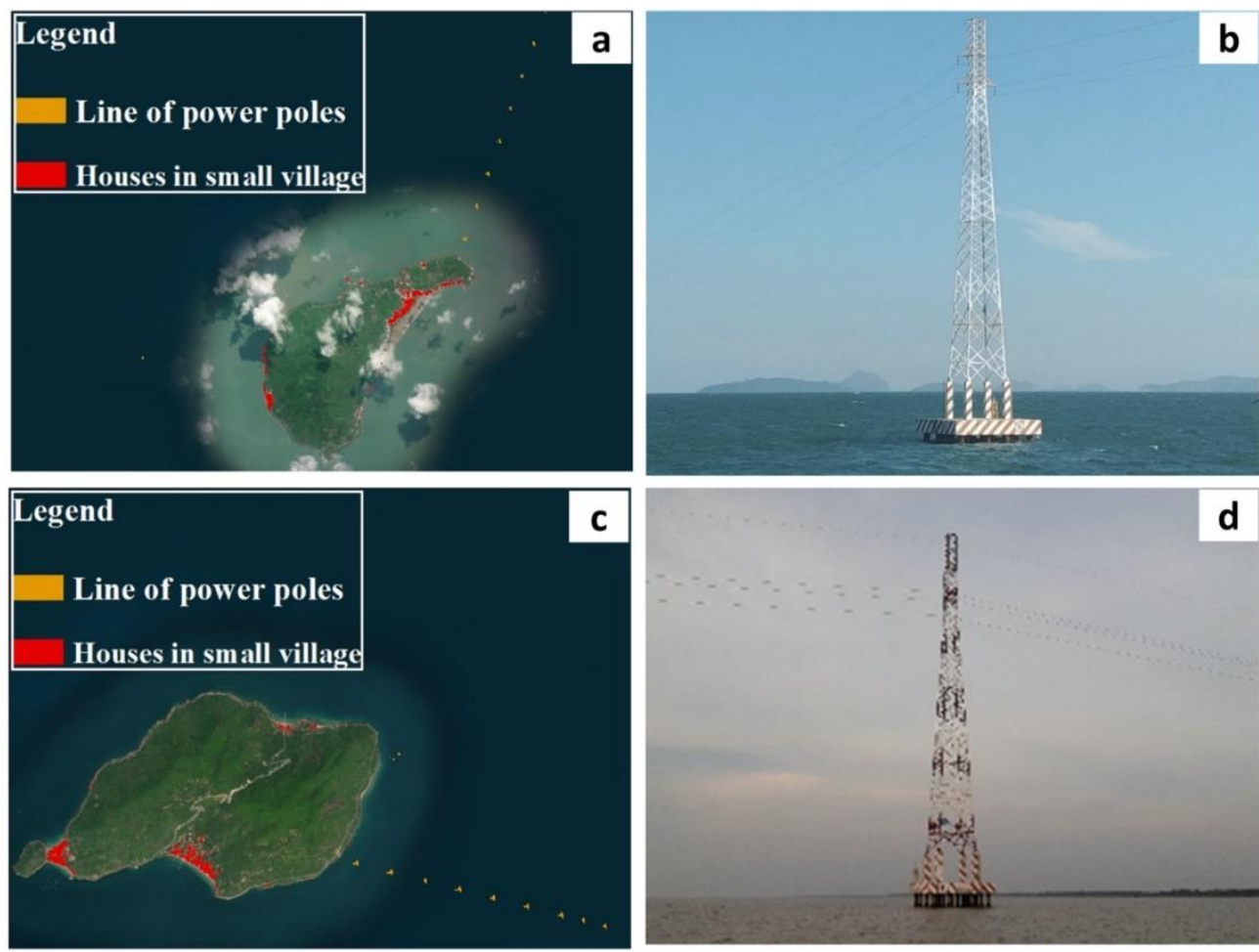

Figure 11. Detection of building structures on sea surfaces in Kiên Giang: (a) electric power line connecting Hòn Tre island to mainland in Kiên Giang, (b) ground-truth photograph on 4 January 2021 at $9^{\circ} 59^{\prime} 55.05^{\prime \prime} \mathrm{N}$ and $104^{\circ} 51^{\prime} 32.20^{\prime \prime} \mathrm{E}$, (c) electric power line connecting Hòn Sơn island to mainland in Kiên Giang, (d) ground-truth photograph on 14 January 2021 at $9^{\circ} 44^{\prime} 48.99^{\prime \prime} \mathrm{N}$ and $104^{\circ} 51^{\prime} 42.47^{\prime \prime} \mathrm{E}$. 
The marine aquaculture in Kiên Giang province (in the Mekong Delta, southern Vietnam) includes farming of blood clams in shallow areas near the shore as a part of the regional development of sustainable fisheries. In 2008, the People Committee of An Biên District issued a policy on an economic development plan for shallow areas along the shore by leasing land, giving loans, and supporting culture techniques to locals. Thanks to this policy, farmers have rented mudflat areas from the local government, and built long wood fences and guard shacks on their farm (Figure 12). They usually live in guard shack month by month to protect their blood clam farm from other fishermen who illegally exploit the blood clams. Gradually, the guard shacks become fishing sites, seafood trading sites, and aqua-tourism sites.
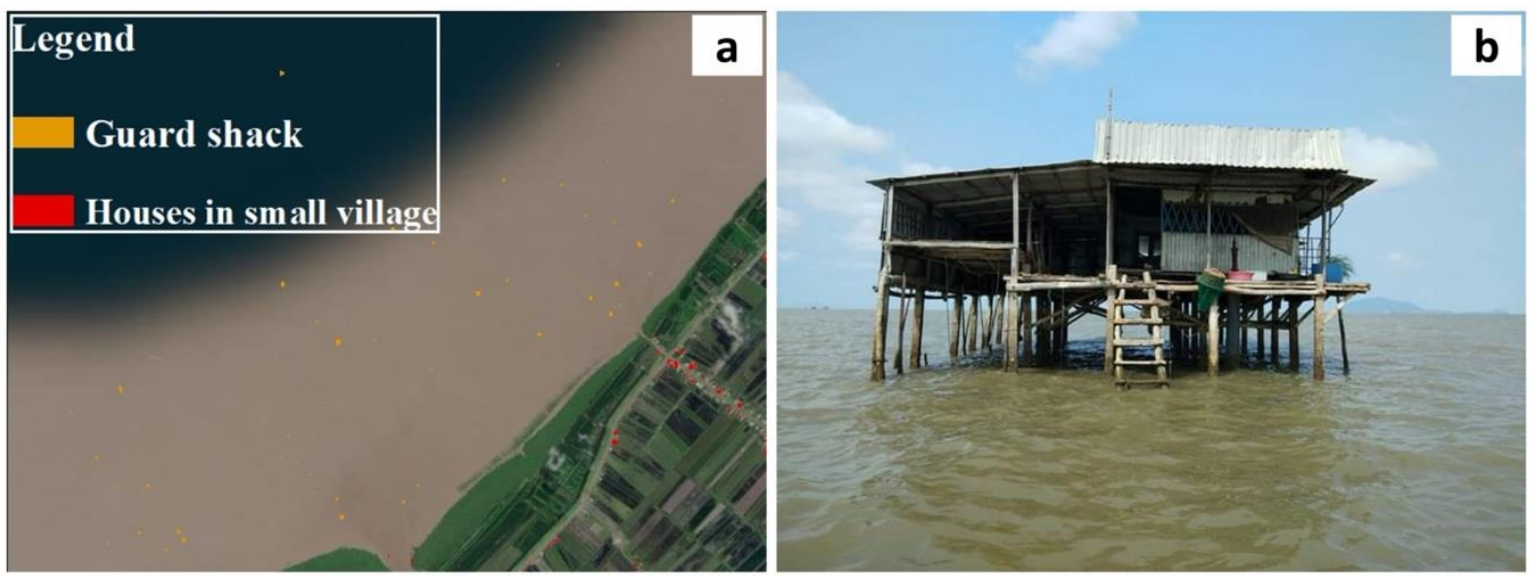

Figure 12. Detection of building structures on shallow areas near the shore in Kiên Giang: (a) guard shacks in blood clam farms in An Biên, (b) ground-truth photograph on 20 February 2021 at $9^{\circ} 53^{\prime} 32.81^{\prime \prime} \mathrm{N}$ and $104^{\circ} 59^{\prime} 1.24^{\prime \prime} \mathrm{E}$.

\section{Discussion}

For the discussion here, we relate the findings presented in this paper to highlight the advances in the innovative SAR methods. First, the use of the 2-D dual-polarization VV-VH space (Figure 3) enabled a robust algorithm to be developed to overcome the confounding effects of complex variations in incidence and azimuth angles of satellite SAR data. This algorithm is important as it allows the use of SAR modes with wide swaths, and therefore more frequent observations with large coverages in comparison with data acquired with narrow swaths. The issue with wide-swath modes is that the range of incidence angles is large (29.1 $1^{\circ}$ to $46.0^{\circ}$ for the Sentinel-1 SAR wide swath mode used in this paper) and changes in backscatter signatures need to be corrected based on the backscatter slope as a function of incidence angles for different land cover classes [20]. Such incidence angle corrections demand a priori knowledge of surface types, which may not be available to start with.

For structures aligned preferentially in a specific direction on land (e.g., houses built along roads, trees grown along river banks, plowed fields in agricultural areas, etc.) and on the sea surface (e.g., waves along shores, roughness on sea surface directionally driven by wind directions, etc.), backscatter signatures can be strongly dependent on the azimuth angles of SAR data acquired in ascending and descending orbit tracks with different azimuth looks. Our new approach for building structure detection using the 2-D VV-VH space is independent of incidence angles and azimuth direction, and thereby resolves the problem due to variations in incidence and azimuth angles.

The 2-D VV-VH space (Figure 3) revealed a distinctive domain for SAR backscatter signatures of building structures explicitly from the domains of multiple land cover types (e.g., trees, paddy fields, aquaculture areas) across the landscape over different regions in southern Vietnam, except for some minor overlap in the VV-VH domain for trees that may have high backscatter. This finding demonstrates the ability of SAR to successfully identify 
building structures across urban-suburban to rural-natural landscapes with different background environments in wet and dry areas from inland to coastal regions. Furthermore, the identification of the overlap between the domains of buildings and trees in the 2-D $\mathrm{VV}-\mathrm{VH}$ space led to the recognition that water-tree interactions in reflection and scattering processes of transmitted and received SAR signals (Figure 4) would cause high backscatter from trees. This prompted the development of the approach using NDVI from Sentinel 2 as an effective method to correct for the misclassification between buildings and trees.

In mountainous regions, land surfaces vary from steep to flat terrains; however, building structures are typically built in areas that are level. The innovative use of the geomorphon concept in our method recognizes this issue, and therefore accounts for the misclassification of building structures caused by topographic effects on SAR signatures (Figure 5). Alternative algorithms that only use land surface height from DEM data would not be sufficient, as flat land may be located at different altitudes from coastal areas, to foothill vicinities, and up on high plateaus. Therefore, the implementation of the full landform characterization with geomorphons is necessary in our method.

On the sea surface, backscatter values in upwind, downwind, and crosswind directions can strongly affect backscatter by an order of magnitude, with low and high wind speeds creating very different wave conditions $[18,19]$. These wind effects confound the detection of man-made structures with different sizes having different backscatter magnitudes. Rather than relying on complicated algorithms such as multi-modal signature decompositions or convolution neural networks that may introduce non-linearity, nonuniqueness, and/or extraneous outcomes, our method overcomes the effects of wind and waves to robustly detect persistent structures on the sea surface, ranging from very large oil platforms to small individual guard shacks in blood clam farms (Figures 9-12).

Our study has further demonstrated the utility of SAR to map building structures in various cities and regions with different environmental and socioeconomic conditions. More specifically, it has shown the ability of Sentinel-1 C-band SAR to make building maps with a high spatial resolution $(10 \mathrm{~m})$ from the SAR data archive since 2014 (Sentinel-1A and 1B) and potentially from future missions (Sentinel-1C and 1D) [38]. Such long-term SAR records are crucial to monitor urban expansion that is continuing in most cities in Vietnam and other countries from the local and provincial to the state and national levels. Moreover, the robust ability to identify structures on the sea surface is important for monitoring coastal developments such as aquacultural farms and both fossil and renewable energy industries in the marine environment.

\section{Conclusions}

This paper has presented an innovative method to detect and map building structures on land and sea using times-series records of satellite Sentinel-1 SAR data. The results were validated with in-situ and field truth observations obtained in southern and central regions of Vietnam. The conclusion from this study includes the following key points:

- The novel use of satellite Sentinel-1 SAR data in the two-dimensional polarization domain enables the method to be robust against confounding factors such as variations due to different incidence and azimuth angles, due to water-tree radar signal interactions (with synergistic Sentinel-2 MSI data), and due to different landforms on complex typography (with the geomorphon concept), without having to rely on more complicated methods such as neural networks that may introduce non-linearity, non-uniqueness, or extraneous outcomes.

- A demonstration of the ability of radar backscatter signatures to detect building structures is founded on radar responses to true physical structures of buildings [5,6], rather than optical colors or spectral appearances of land cover types. As our method is based on radar signatures of physical building structures, it can successfully capture the characteristics of urban building patterns corresponding to different urban development classes and socioeconomic status (see Tables 1 and 2), and in differ- 
ent rural-urban landscapes in both inland and coastal regions with wet and arid environmental conditions, or over sea surfaces under different wind and wave effects.

- Founded on time-series satellite SAR data records consistently tracked at each pixel location, the method successfully detects and maps persistent (rather than temporary) building structures, which truly represent sustained human settlements in order to circumvent the shortfalls of the proxy indicator derived from NTL data [4], as illustrated in the case of Phan Thiết city versus the dragon fruit plantations in Bình Thuận (Figure 8). Such spatial data products of physical building structures are crucial for urban mapping applications, in particular for accurate estimations of FFCO2 emission required for the successful implementation of the UNFCCC Paris Agreement. In fact, the U.S. National Academies of Sciences, Engineering, and Medicine recognizes that the improvement in greenhouse gas (GHG, including FFCO2) measurement and monitoring is foundational to the control of global GHG emissions [39].

Regarding future research extension, the algorithm in this paper can be modified or adapted for use with SAR data at other frequencies such as X band (the current TerraSAR$X /$ TanDEM-X and COSMO-SkyMed satellite SAR Missions and the future LOTUSat 1 and 2 satellite SAR Missions in the 2020s), L band (the current ALOS-2 PALSAR-2 Mission and the future Copernicus ROSE-L Mission), and combined L band and S band (the NASAISRO SAR Mission to be launched in 2022). A synergistic combination of satellite SAR datasets offers a great potential to derive global building structure data products over a wide range of temporal and spatial scales, not only for two-dimensional building footprint, but also potentially for three-dimensional building volume [40].

Author Contributions: K.D.N. implemented the algorithms, collected extensive ground truth data and field observations, carried out data analyses and validations, and drafted the paper. S.V.N. developed the methods, directed the algorithm implementations, contributed field observations for the validation assessment, and wrote multiple parts of the paper. A.M.L. advised K.D.N. as a graduate student in this research and contributed to the writing of this paper. T.T.V. is also K.D.N.'s adviser and contributed to overall revision of this paper. All authors have read and agreed to the published version of the manuscript.

Funding: The research carried out at the Jet Propulsion Laboratory, California Institute of Technology, was funded under a contract with the National Aeronautics and Space Administration (80NM0018D0004).

Acknowledgments: The research carried out at the Jet Prolusion Laboratory, California Institute of Technology was supported by the NASA Land Cover and Land Use Change (LCLUC) Program and in part by the NASA Earth Science R\&A Program. We appreciate the coordination by NASA Headquarters, NASA Office of International and Interagency Relations, NASA Jet Propulsion Laboratory, U.S. Department of State in Washington D.C., U.S. Embassy in Hanoi, U.S. Consulate in Hồ Chí Minh City, Vietnam National Space Center, and universities in the U.S. and Vietnam to arrange for meetings leading to international and multi-institutional science collaborations, among which is the research presented in this paper.

Conflicts of Interest: The authors declare no conflict of interest.

\section{Appendix A}

Figure A1 shows the plot of number of pixels versus threshold, and the plot of the discrete derivative of building pixels versus threshold for Bạc Liêu, Cà Mau, Sóc Trăng, Tân An, and Phan Thiêt. The plots show that threshold $=9$ (i.e., building count $=10$ or more) is optimal as the derivative curves are flattened for larger threshold values. This means that the building detection results converge and become stable so that the inclusion of an excessively large threshold count is ineffective and unnecessary. It is noted that threshold $=9$ is found valid for all cities in various environments from wet to dry regions and from in-land areas to coastal zones, across the landscape from natural and rural to urban conditions. The building count of at least 10 signifies that the building structure 
must persistently exist for a minimum period consisting of 9 two-week intervals (Sentinel-1

SAR revisit time is two weeks), which is equivalent to 18 weeks or 4.15 months.

(a)

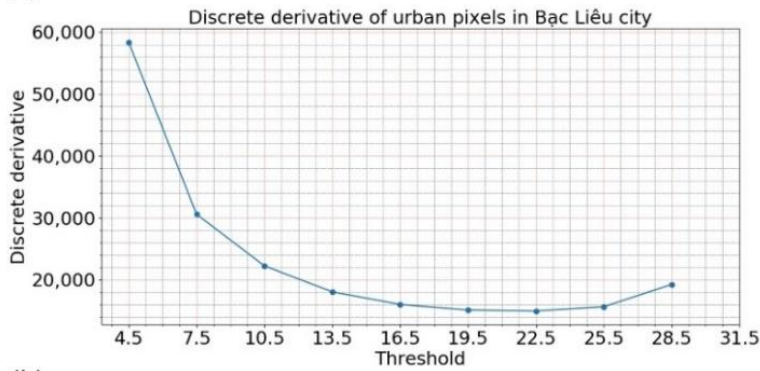

(b)

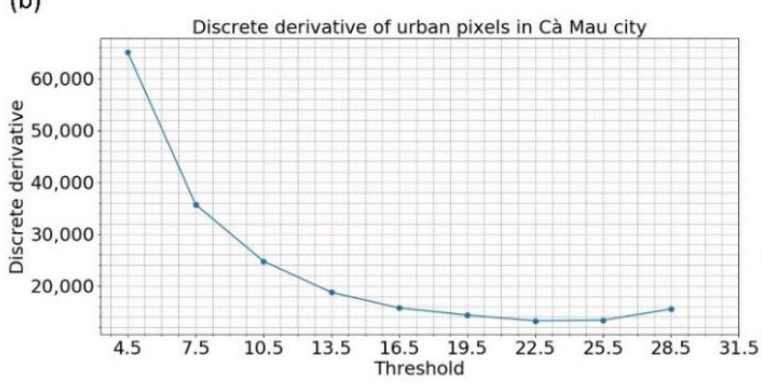

(c)

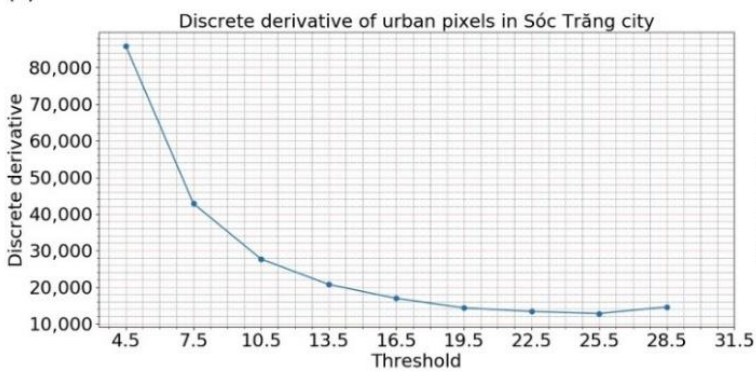

(d)

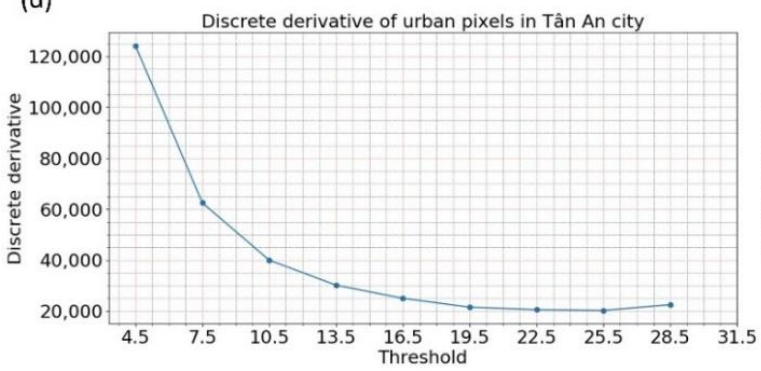

(e)

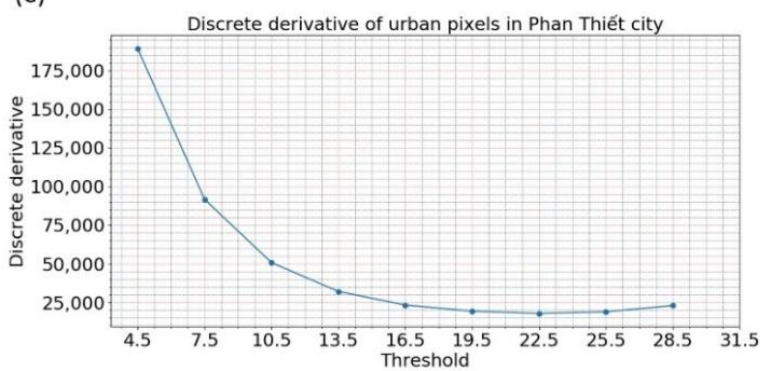

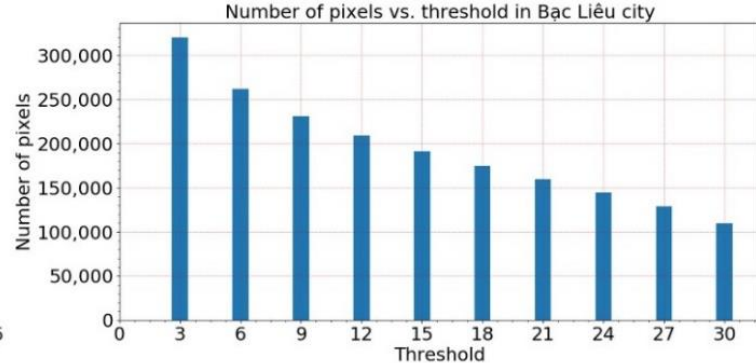
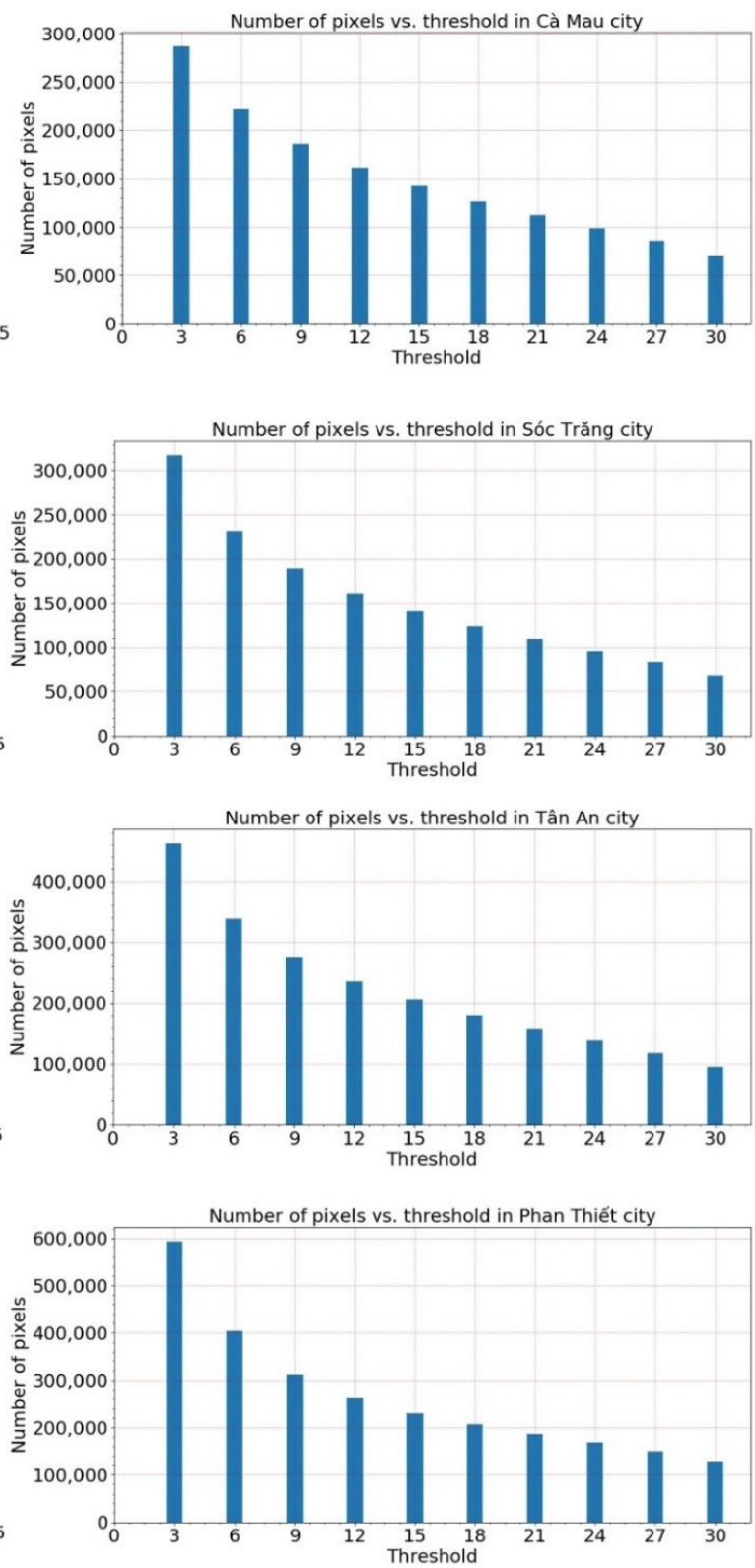

Figure A1. Discrete derivative of building pixel vs. threshold in (a) Bạc Liêu, (b) Cà Mau, (c) Sóc Trăng, (d) Tân An, and (e) Phan Thiêt. 


\section{References}

1. Lwin, K.; Murayama, Y.A. GIS Approach to Estimation of Building Population for Micro-Spatial Analysis. Trans. GIS 2009, 13, 401-414. [CrossRef]

2. Mathews, A.J.; Frazier, A.E.; Nghiem, S.V.; Neumann, G.; Zhao, Y. Satellite Scatterometer Estimation of Urban Built-up Volume: Validation with Airborne Lidar Data. Int. J. Appl. Earth Obs. Geoinf. 2019, 77, 100-107. [CrossRef]

3. Xiao, Y.; Zhan, Q. A Review of Remote Sensing Applications in Urban Planning and Management in China. 2009 Jt. Urban Remote Sens. Event 2009, 1-5. [CrossRef]

4. Gaughan, A.E.; Oda, T.; Sorichetta, A.; Stevens, F.R.; Bondarenko, M.; Bun, R.; Krauser, L.; Yetman, G.; Nghiem, S.V. Evaluating Nighttime Lights and Population Distribution as Proxies for Mapping Anthropogenic CO 2 Emission in Vietnam, Cambodia and Laos. Environ. Res. Commun. 2019, 1, 091006. [CrossRef]

5. Sorichetta, A.; Nghiem, S.V.; Masetti, M.; Linard, C.; Richter, A. Transformative Urban Changes of Beijing in the Decade of the 2000s. Remote Sens. 2020, 12, 625. [CrossRef]

6. Nghiem, S.V.; Balk, D.; Rodriguez, E.; Neumann, G.; Sorichetta, A.; Small, C.; Elvidge, C.D. Observations of Urban and Suburban Environments with Global Satellite Scatterometer Data. ISPRS J. Photogramm. Remote Sens. 2009, 64, 367-380. [CrossRef]

7. Ban, Y.; Webber, L.; Gamba, P.; Paganini, M. EO4Urban: Sentinel-1A SAR and Sentinel-2A MSI Data for Global Urban Services. In Proceedings of the 2017 Joint Urban Remote Sensing Event (JURSE), Dubai, United Arab Emirates, 6-8 March 2017; pp. 1-4. [CrossRef]

8. Lisini, G.; Salentinig, A.; Du, P.; Gamba, P. SAR-Based Urban Extents Extraction: From ENVISAT to Sentinel-1. IEEE J. Sel. Top. Appl. Earth Obs. Remote Sens. 2018, 11, 2683-2691. [CrossRef]

9. Gamba, P.; Lisini, G. Fast and Efficient Urban Extent Extraction Using ASAR Wide Swath Mode Data. IEEE J. Sel. Top. Appl. Earth Obs. Remote Sens. 2013, 6, 2184-2195. [CrossRef]

10. Esch, T.; Marconcini, M.; Felbier, A.; Roth, A.; Heldens, W.; Huber, M.; Schwinger, M.; Taubenböck, H.; Müller, A.; Dech, S. Urban Footprint Processor-Fully Automated Processing Chain Generating Settlement Masks From Global Data of the TanDEM-X Mission. IEEE Geosci. Remote Sens. Lett. 2013, 10, 1617-1621. [CrossRef]

11. Esch, T.; Bachofer, F.; Heldens, W.; Hirner, A.; Marconcini, M.; Palacios-Lopez, D.; Roth, A.; Üreyen, S.; Zeidler, J.; Dech, S.; et al. Where We Live-A Summary of the Achievements and Planned Evolution of the Global Urban Footprint. Remote Sens. 2018, 10, 895. [CrossRef]

12. Zhang, K.; Fu, X.; Lv, X.; Yuan, J. Unsupervised Multitemporal Building Change Detection Framework Based on Cosegmentation Using Time-Series SAR. Remote Sens. 2021, 13, 471. [CrossRef]

13. Manzoni, M.; Monti-Guarnieri, A.; Molinari, M.E. Joint exploitation of spaceborne SAR images and GIS techniques for urban coherent change detection. Remote Sens. Environ. 2021, 253. [CrossRef]

14. Holobâcă, I.-H.; Ivan, K.; Alexe, M. Extracting built-up areas from Sentinel-1 imagery using land-cover classification and texture analysis. Int. J. Remote Sens. 2019, 40, 8054-8069. [CrossRef]

15. Corbane, C.; Lemoine, G.; Pesaresi, M.; Kemper, T.; Sabo, F.; Ferri, S.; Syrris, V. Enhanced automatic detection of human settlements using Sentinel-1 interferometric coherence. Int. J. Remote Sens. 2018, 39, 842-853. [CrossRef]

16. Kong, J.A. Electromagnetic Wave Theory, 2nd ed.; Wiley-Interscience: New York, NY, USA, 1990.

17. Nghiem, S.V.; Borgeaud, M.; Kong, J.A.; Shin, R.T. Polarimetric Remote Sensing of Geophysical Media with Layer Random Medium Model. In Progress in Electromagnetics Research; Kong, J.A., Ed.; Elsevier: Amsterdam, The Netherlands, 1990; Volume 3, pp. 1-73.

18. Nghiem, S.V.; Li, F.K.; Lou, S.H.; Neumann, G.; McIntosh, R.E.; Carson, S.C.; Carswell, J.R.; Walsh, E.J.; Walsh, E.J.; Donelan, M.A.; et al. Observations of Radar Backscatter at $\mathrm{Ku}$ and $\mathrm{C}$ Bands in the Presence of Large Waves during the Surface Wave Dynamics Experiment. IEEE Trans. Geosci. Remote Sens. 1995, 33, 708-721. [CrossRef]

19. Carswell, J.R.; Mcintosh, R.E.; Carson, S.C.; Li, F.K.; Neumann, G.; Nghiem, S.V.; Mclaughlin, D.J.; Wilkerson, J.C.; Black, P.G. Airborne Scatterometers: Investigating Ocean Backscatter under Low- and High-Wind Conditions. Proc. IEEE 1994, 82, 1835-1860. [CrossRef]

20. Phung, H.-P.; Nguyen, L.-D.; Thong, N.-H.; Thuy, L.-T.; Apan, A.A. Monitoring Rice Growth Status in the Mekong Delta, Vietnam Using Multitemporal Sentinel-1 Data. J. Appl. Remote Sens. 2020, 14, 1. [CrossRef]

21. Jasiewicz, J.; Stepinski, T.F. Geomorphons-A Pattern Recognition Approach to Classification and Mapping of Landforms. Geomorphology 2013, 182, 147-156. [CrossRef]

22. Veselský, M.; Bandura, P.; Burian, L.; Harciníková, T.; Bella, P. Semi-automated recognition of planation surfaces and other flat landforms: A case study from the Aggtelek Karst, Hungary. Open Geosci. 2015, 7, 799-811. [CrossRef]

23. da Silveira, C.T.; Silveira, R.M.P.; Trentin, R.; Robaina, L.E.D. Automated Classification of Landform Elements in the State Of Parana (Brazil) Applying the Proposal of the Geomorphons. Rev. Brasi. Geomorf. 2018, 19, 33-57. [CrossRef]

24. Gawrysiak, L.; Kociuba, W. Application of geomorphons for analysing changes in the morphology of a proglacial valley (case study: The Scott River, SW Svalbard). Geomorph 2020, 371, 107449. [CrossRef]

25. Shuttle Radar Topography Mission, The Mission to Map the World. Available online: https://www2.jpl.nasa.gov/srtm/ (accessed on 11 November 2020).

26. Kramm, T.; Hoffmeister, D.; Curdt, C.; Maleki, S.; Khormali, F.; Kehl, M. Accuracy Assessment of Landform Classification Approaches on Different Spatial Scales for the Iranian Loess Plateau. ISPRS Int. J. Geo Inf. 2017, 6, 366. [CrossRef] 
27. Barsi, A.; Kugler, Z.; László, I.; Szabó, G.; Abdulmutalib, H.M. Accuracy Dimensions in Remote Sensing. Int. Arch. Photogramm. Remote Sens. Spat. Inf. Sci. ISPRS Arch. 2018, 42, 61-67. [CrossRef]

28. Xây Dựng, T.P. Bạc Liêu Trở Thành Đô Thị Loại I Vào Năm 2025. Available online: https:/ / nongnghiep.vn/xay-dung-tp-baclieu-tro-thanh-do-thi-loai-i-vao-nam-2025-d272784.html (accessed on 10 September 2020).

29. Mau, C. Thành Phố Trẻ Hội Nhập, Phát Triển. Available online: http://moc.gov.vn/vn/tin-tuc/1184/63988/ca-mau--thanhpho-tre-hoi-nhap--phat-trien.aspx (accessed on 13 November 2020).

30. Công Bố Chương Trình Phát Triển Đô Thị TP. Sóc Trăng Đến Năm 2030. Available online: http:/ / baosoctrang.org.vn/thanh-phosoc-trang-tren-duong-phat-trien/cong-bo-chuong-trinh-phat-trien-do-thi-tp-soc-trang-den-nam-2030-40825.html (accessed on 13 November 2020).

31. Long, A. Phát Triển Đô Thị, Tạo Động Lực Thúc Đẩy Kinh Tế. Available online: http://moc.gov.vn/vn/tin-tuc/1184/64077 /long-an--phat-trien-do-thi--tao-dong-luc-thuc-day-kinh-te.aspx (accessed on 13 November 2020).

32. Xây Dựng Đô Thị Phan Thiết Phát Triển Bền Vững và Thân Thiện Với Môi Trường. Available online: http://phanthiet. gov.vn/bai-viet/xay-dung-do-thi-phan-thiet-phat-trien-ben-vung-va-than-thien-voi-moi-truong-3626.html (accessed on 13 November 2020).

33. Congress Committee. Về Phân Loại Đô Thị; Congress Committee: Ha Noi, Vietnam, 2016.

34. Earth Observation Group. See the World at Night, VIIRS Nighttime Light. Available online: https://eogdata.mines.edu/ products/vnl/ (accessed on 29 April 2021).

35. Rockwell, N.C.; Lagaris, J.C. The Structure of Phytochrome: A Picture Is Worth a Thousand Spectra. Plant Cell 2006, 18, 4-14. [CrossRef] [PubMed]

36. Zee, F.; Yen, C.-R.; Nishina, M. Pitaya (Dragon Fruit, Strawberry Pear); FN-9; University of Hawaii: Honolulu, HI, USA, 2004; 3p.

37. Paull, R.E.; Chen, N.J. Overall Dragon Fruit Production and Global Marketing, FTTC Agricultural Marketing Policy. Taipei, Taiwan. 2019. Available online: http:/ /ap.fftc.agnet.org/ap_db.php?id=1036\&print=1 (accessed on 4 May 2020).

38. ESA. Sentinel-1. Available online: https://sentinel.esa.int/web/sentinel/missions/sentinel-1 (accessed on 3 May 2021).

39. National Academies of Sciences, Engineering, and Medicine. Research on Approaches Critical to Managing Climate Risk. In Global Change Research Needs and Opportunities for 2022-2031; The National Academies Press: Washington, DC, USA, 2021; Volume 4, pp. 37-42. [CrossRef]

40. Mathews, A.J.; Nghiem, S.V. Examining urban built-up volume: Three-dimensional analyses with lidar and radar data. In Urban Remote Sensing: Monitoring, Synthesis and Modeling in the Urban Environment, 2nd ed.; Yang, X., Ed.; Wiley: Hoboken, NJ, USA, 2021; in press. 